\title{
Highly active heterogeneous catalyst for ethylene dimerization prepared by selectively doping Ni on the surface of a zeolitic imidazolate framework
}

Cailing Chen, ${ }^{1 \#}$ Mohammed R. Alalouni, ${ }^{1 \#}$ Xinglong Dong, ${ }^{1 \#}$ Zhen Cao, ${ }^{2}$ Qingpeng Cheng, ${ }^{1}$ Lirong Zheng, ${ }^{3}$ Lingkun Meng, ${ }^{4}$ Chao Guan, ${ }^{2}$ Lingmei Liu, ${ }^{1}$ Edy Abou-Hamad, ${ }^{5}$ Jianjian Wang, ${ }^{6}$ Zhan Shi, ${ }^{4}$ Kuo-Wei Huang, ${ }^{2}$ Luigi Cavallo, ${ }^{2}$ Yu Han ${ }^{1}$,

${ }^{1}$ King Abdullah University of Science and Technology (KAUST), Physical Sciences and Engineering Division, Advanced Membranes and Porous Materials (AMPM) Center, Thuwal 23955-6900, Saudi Arabia

${ }^{2}$ King Abdullah University of Science and Technology, Physical Sciences and Engineering Division, KAUST Catalysis Center, 23955-6900 Thuwal, Saudi Arabia

${ }^{3}$ Beijing Synchrotron Radiation Facility, Institute of High Energy Physics, Chinese Academy of Sciences, Beijing, 100049, P. R. China.

${ }^{4}$ State Key Laboratory of Inorganic Synthesis and Preparative Chemistry, Jilin University, 2699 Qianjin Street, Changchun 130012, P. R. China

${ }^{5}$ Imaging and Characterization Core Lab, KAUST, Thuwal 23955-6900, Saudi Arabia.

${ }^{6}$ Multi-scale Porous Materials Center, Institute of Advanced Interdisciplinary Studies, \& School of Chemistry and Chemical Engineering, Chongqing University, Chongqing 400044, P. R. China.

Correspondence to: yu.han@kaust.edu.sa 


\section{Material Synthesis}

Synthesis of Ni-ZIF-8. Pure ZIF-8 was synthesized from the following procedure: $50 \mathrm{~mL}$ of methanol solution $\left[\mathrm{Zn}\left(\mathrm{NO}_{3}\right)_{2} \cdot 6 \mathrm{H}_{2} \mathrm{O}, 0.1 \mathrm{M}\right.$ ] and $40 \mathrm{~mL}$ of methanol solution [2-methylimidazole, $1 \mathrm{M}$ ] were mixed and stirred at room temperature for 10 hours (the molar ratio of $\mathrm{Zn}$ to 2-methylimidazole is 1:8); the obtained product was collected by centrifugation and thoroughly washed with methanol. The Ni-ZIF-8 samples were synthesized by following the same procedure, except that $\mathrm{Zn}\left(\mathrm{NO}_{3}\right)_{2} \cdot 6 \mathrm{H}_{2} \mathrm{O}$ was replaced by the mixture of $\mathrm{Zn}\left(\mathrm{NO}_{3}\right)_{2} \cdot 6 \mathrm{H}_{2} \mathrm{O}$ and $\mathrm{Ni}\left(\mathrm{NO}_{3}\right)_{2} \cdot 6 \mathrm{H}_{2} \mathrm{O}$, while keeping the total molar amount of metal sources identical. Four Ni-ZIF-8 samples were prepared by varying the molar percentage of $\mathrm{Ni}$ in the total metal $(\mathrm{Ni}+\mathrm{Zn})$ in the precursor $(15 \%, 30 \%, 45 \%$, and $60 \%)$. The $\mathrm{Ni}$ contents in the obtained $\mathrm{Ni}-\mathrm{ZIF}-8$ samples were determined to be $0.08 \mathrm{wt} \%, 0.20 \mathrm{wt} \%, 0.40 \mathrm{wt} \%$, and $0.70 \mathrm{wt} \%$, respectively.

Synthesis of Ni-ZIF-8@ZIF-8. The core-shell structured Ni-ZIF-8@ZIF-8 sample was synthesized using a reported method ${ }^{\mathrm{S} 1}$ with slight modification: $200 \mathrm{mg}$ of Ni-ZIF-8 (0.70 wt\% Ni loading) was dispersed in $60 \mathrm{~mL}$ of methanol via ultrasonication, followed by the addition of $360 \mathrm{mg}$ of $\mathrm{Zn}\left(\mathrm{NO}_{3}\right)_{2} \cdot 6 \mathrm{H}_{2} \mathrm{O} .1 .2 \mathrm{~g}$ of 2methylimidazole was dissolved into $30 \mathrm{~mL}$ of methanol, and then, the obtained solution was poured into the above suspension containing Ni-ZIF-8. The mixture was stirred at room temperature for 24 hours. The product was collected by centrifugation and thoroughly washed with methanol.

Synthesis of Cu-ZIF-8. The Cu-ZIF-8 was synthesized according to previous report. ${ }^{S 2}$ Specifically, $\mathrm{Zn}\left(\mathrm{NO}_{3}\right)_{2} \cdot 6 \mathrm{H}_{2} \mathrm{O}(520.55 \mathrm{mg}, 1.75 \mathrm{mmol})$ and $\mathrm{Cu}\left(\mathrm{NO}_{3}\right)_{2} \cdot 3 \mathrm{H}_{2} \mathrm{O}(60.4 \mathrm{mg}, 0.25 \mathrm{mmol})$ were dissolved in 22.6 $\mathrm{mL}$ of methanol; 2-methylimidazole $(1320 \mathrm{mg}, 16 \mathrm{mmol}$ ) was dissolved in $22.6 \mathrm{~mL}$ of methanol separately. The 2-methylimidazole solution was dropwise added to the $\mathrm{Zn}^{2+} / \mathrm{Cu}^{2+}$ solution in a two-neck flask under nitrogen flow with stirring over $1 \mathrm{~h}$ and the mixed solution was allowed to stand for $24 \mathrm{~h}$ at room temperature. The obtained Cu-doped ZIF-8 crystals were separated by centrifugation (4500 rpm, $15 \mathrm{~min})$, washed with methanol $(3 \times 30 \mathrm{~mL})$, and dried at $60^{\circ} \mathrm{C}$ for $6 \mathrm{~h}$.

\section{Catalytic Reactions}

Ethylene dimerization. The catalytic ethylene dimerization experiment was performed in a Parr stainless steel autoclave reactor ( $75 \mathrm{~mL}$, from Parr Series 5000 Multiple Reactor System). In a typical run, catalyst (15 mg), solvent (20 mL of dried toluene), and a specified number of equivalents of MAO (10 wt\% in 
toluene) were loaded into Parr autoclave reactor in the glovebox. Then, the reactor was sealed and transferred out of the glovebox. The reactor was heated to the desired temperature, stirred, and connected to the ethylene cylinder. After $10 \mathrm{~min}$ of reaction, the reactor was cooled down in a dry ice/acetone bath. When the internal temperature reached $-20{ }^{\circ} \mathrm{C}$, the reactor was slowly vented to atmospheric pressure. The reactor was opened and $0.1 \mathrm{~mL}$ of cooled cyclopentene was added to the solution to serve as an internal standard. Then, ice-cold deionized water was added into the reaction solution before the organic layer was filtered through a precooled syringe filter. The organic layer was quickly analyzed via gas chromatography equipped with a flame ionization detector (FID) and a HP-PONA column. In different reaction tests, the amounts of catalyst and MAO, pressure of ethylene, reaction temperature, and reaction time were adjusted as needed.

Isotopic labeling experiment. Ni-ZIF-8 with $0.7 \mathrm{wt} \% \mathrm{Ni}(15 \mathrm{mg}), \mathrm{MAO}$ (10 wt\% Al in toluene, $1 \mathrm{~mL})$, and toluene $(5 \mathrm{~mL})$ were added into Parr autoclave reactor in an argon-filled glovebox. Then, the reactor was sealed and transferred out of the glovebox and degassed for a while. Upon completion of pumping, a gas mixture of ethylene $(5 \mathrm{~mL} / \mathrm{min})$ and $\mathrm{d}_{4}$-ethylene $(5 \mathrm{~mL} / \mathrm{min})$ with a total flow rate of $10 \mathrm{~mL} / \mathrm{min}$ was introduced into the reactor. Before being injected into the reactor, ethylene and $\mathrm{d}_{4}$-ethylene were premixed in the fully vented gas line for $10 \mathrm{~min}$. After $5 \mathrm{~min}$ of reaction, the products were collected following the procedure described above. The organic layer was filtered through a precooled syringe filter, and then quickly analyzed via gas chromatography/mass spectrometry equipped with an HP-PONA column.

\section{Evaluation of the catalytic stability of Ni-ZIF-8.}

$30 \mathrm{mg}$ of Ni-ZIF-8 (0.7 wt\% Ni) was dispersed into $30 \mathrm{~mL}$ toluene. $1 \mathrm{~mL}$ of the catalyst solution, $4 \mathrm{~mL}$ of toluene, and $0.25 \mathrm{~mL}$ of MAO were loaded into the Parr autoclave reactor in the glovebox. Then, the reactor was sealed and transferred out of the glovebox. The reactor was heated to $35{ }^{\circ} \mathrm{C}$, stirred, and connected to the ethylene cylinder (30 bar). The reaction was conducted for the desired time (10 min, 1 $\mathrm{h}, 2 \mathrm{~h}$, and $4 \mathrm{~h}$ ). After the reaction, the reactor was cooled down in a dry ice/acetone bath. The procedure of product collection and analysis was the same as described above. 


\section{Materials Characterization}

X-ray absorption spectroscopy. X-ray absorption measurements were carried out at 1W1B beamline in Beijing Synchrotron Radiation Facility (BSRF). The X-ray Absorption Fine Structure (XAFS) data were collected in the fluorescence mode through a Si (111) double crystal monochromator. Ni foil, NiPc, Zn foil, and ZnO were used as reference compounds for X-ray Absorption Near Edge Structure (XANES) and Extended X-ray Absorption Fine Structures (EXAFS) analysis. The data were processed and analyzed using the Demeter 0.9.26 software package.

Electron Microscopy. Scanning TEM (STEM) imaging and Energy-dispersive X-ray spectroscopy (EDS) elemental analysis experiments were performed on an FEI Titan 80-300 microscope equipped with a probe Cs corrector, operated at $300 \mathrm{kV}$. Low-magnification TEM images and high-resolution TEM imaging was performed on an FEI Titan 80-300 microscope equipped with an image Cs corrector, operated at 300 kV.

Solid-State Nuclear Magnetic Resonance Spectroscopy. One dimensional ${ }^{15} \mathrm{~N} \mathrm{CP} / \mathrm{MAS}$ solid-state NMR spectra were recorded on a Bruker AVANCE III spectrometer operating at $900 \mathrm{MHz}$ for ${ }^{1} \mathrm{H}$, with a conventional double resonance $4 \mathrm{~mm} \mathrm{CP/MAS} \mathrm{probe.} \mathrm{Dry} \mathrm{nitrogen} \mathrm{gas} \mathrm{was} \mathrm{utilized} \mathrm{for} \mathrm{sample} \mathrm{spinning}$ to prevent degradation of the samples. NMR chemical shifts are reported with respect to the external references TMS and adamantine for ${ }^{1} \mathrm{H}$ and $\mathrm{NH}_{3}(0 \mathrm{ppm})$ for ${ }^{15} \mathrm{~N}$. The spinning frequency was set to 13 $\mathrm{kHz}$. The following sequence was used: 900 pulses on the proton (pulse length $2.4 \mathrm{~s}$ ), then a crosspolarization step with a contact time of $2 \mathrm{~ms}$, and finally the acquisition of the ${ }^{15} \mathrm{~N}$ signal under high power proton decoupling. The delay between the scan was set to $5 \mathrm{~s}$, to allow the complete relaxation of the ${ }^{1} \mathrm{H}$ nuclei and the number of scans was 50.000. An apodization function (exponential) corresponding to a line broadening of $80 \mathrm{~Hz}$ was applied prior to Fourier transformation.

Powder X-ray diffraction. Powder X-ray diffraction (PXRD) patterns were recorded on Bruker D8 Advance instrument with $\mathrm{Cu} \mathrm{K}_{\alpha}$ radiation $(\lambda=0.1542 \mathrm{~nm})$. The tube voltage and current were $40 \mathrm{kV}$ and $40 \mathrm{~mA}$, respectively.

Electron paramagnetic resonance. The electron paramagnetic resonance (EPR) spectra were obtained on a JES-FA 200 EPR spectrometer. To verify the reliability of the EPR measurements, we synthesized CuZIF-8 as a reference sample by following a reported method. ${ }^{\text {S2 }}$ The Cu loading in Cu-ZIF-8 (0.80 wt\%) is 
similar with the Ni loading in Ni-ZIF-8 (Ni: 0.70 wt\%). In the EPR spectra, Cu-ZIF-8 shows a strong signal of unpaired electrons associated with metal centers, whereas Ni-ZIF-8 does not.

$\mathbf{N}_{2}$ gas adsorption measurements. A Micromeritics ASAP 2020 Surface Area and Porosity Analyzer was used to collect nitrogen sorption isotherms at $77 \mathrm{~K}$.

Inductively coupled plasma optical emission spectrometry. Inductively coupled plasma optical emission spectrometry (ICP-OES) measurements were carried out on an Agilent 5110 spectrometer.

\section{Theoretical calculations}

Geometry optimizations were performed at the density functional theory (DFT) level using the generalized-gradient approximation (GGA) PBE functional ${ }^{\mathrm{S3}}$ with Becke-Johnson damped D3 ${ }^{\mathrm{S4}}$ dispersion correction as implemented in Gaussian09. ${ }^{55}$ To reduce computational cost, an automatic density fitting set generated by the Gaussian program was used. The def2SVPS6 basis set was used for $\mathrm{H}, \mathrm{C}$ and $\mathrm{N}$ atoms, $\mathrm{Ni}$ was treated with the def2TVP basis set, ${ }^{\mathrm{S7}}$ whereas for $\mathrm{Zn}$ we used the SDD ${ }^{\mathrm{S8}}$ pseudopotential with the associated triple- $\zeta$ basis set. Single point energy calculations were carried out using the def2-TZVP Ahlrichs basis set ${ }^{\mathrm{S7}}$ for $\mathrm{H}, \mathrm{C}$, and $\mathrm{N}$, and the SDD ECP for Ni and $\mathrm{Zn}$. All geometry optimizations were performed in the gas phase. The nature of all stationary points was confirmed by analytic computation of vibrational frequencies, which were also employed for the computation of thermochemical quantities. Gibbs free energies were computed by adding Gibbs free energy contributions to single-point calculations taking the separated reactants as zero of energy.

The computational cluster model (Figure 1) was carved from the bulk crystal. It contains four metal centers including one $\mathrm{Ni}$ and three $\mathrm{Zn}$, and the metal atoms are coordinated by bridging ligands. For $\mathrm{Zn}$ atoms, each one is coordinated with four imidazole rings, while the Ni atom is coordinated with three imidazole rings and one nitrate. The ligands form a planar structure at the Ni center, which is consistent with experimental characterizations. 
Table S1. The calculated Ni site densities on various Ni-ZIF-8 catalysts ${ }^{\text {a }}$

\begin{tabular}{c|ccc}
\hline Catalyst & $\begin{array}{c}\text { Nickel loading } \\
\text { (wt\%) }\end{array}$ & $\begin{array}{c}\text { External surface area } \\
\left(\mathbf{m}^{\mathbf{2}} \mathbf{g}\right)\end{array}$ & $\begin{array}{c}\text { Ni site density } \\
\left(\mathbf{n m}^{-\mathbf{2}}\right)\end{array}$ \\
\hline Ni-ZIF-8(0.70 wt\%) & 0.70 & 152.5 & 0.5 \\
\hline Ni-ZIF-8(0.40 wt\%) & 0.40 & 105.1 & 0.41 \\
\hline Ni-ZIF-8(0.20 wt\%) & 0.20 & 82.9 & 0.26 \\
\hline Ni-ZIF-8(0.08 wt\%) & 0.08 & 71.9 & 0.12 \\
\hline
\end{tabular}

${ }^{a}$ The calculations of $\mathrm{Ni}$ site density were based on the $\{110\}$ surface structure of ZIF-8, Ni loading determined by ICP$\mathrm{OES}$, and the external surface areas derived from $\mathrm{N}_{2}$ sorption measurements. 
Table S2. Optimized local coordination structure of $\mathrm{Ni}$ in Ni-ZIF-8.

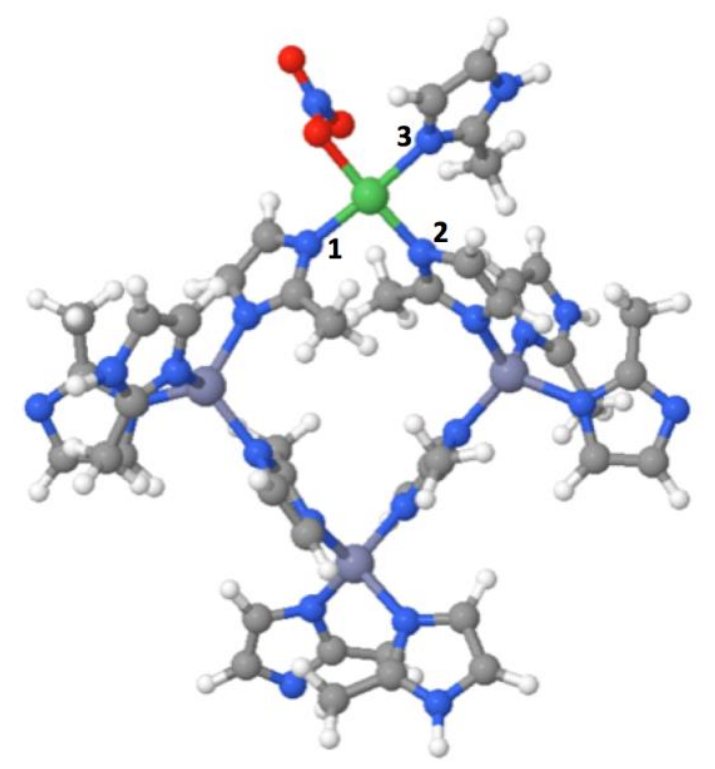

\begin{tabular}{cccccccc}
\hline \multicolumn{3}{c}{ Bond Length } & \multicolumn{4}{c}{ Bond Angle } \\
\hline Ni-N1 & Ni-N2 & Ni-N3 & Ni-O & N1-Ni-N2 & N2-Ni-N3 & N3-Ni-O & O-Ni-N1 \\
$1.88 \AA$ & $1.88 \AA$ & $1.92 \AA$ & $1.89 \AA$ & $92.7^{\circ}$ & $90.6^{\circ}$ & $86.8^{\circ}$ & $89.9^{\circ}$ \\
\hline
\end{tabular}


Table S3. Catalytic results and reaction conditions of some selected Ni-based homogeneous and heterogeneous catalysts for ethylene dimerization

\begin{tabular}{|c|c|c|c|c|c|}
\hline $\begin{array}{l}\text { Reaction duration } \\
\text { (min) }\end{array}$ & $\begin{array}{l}\text { Turnover number }{ }^{\mathrm{a}} \\
\text { (mol ethylene/mol } \mathrm{Ni} \text { ) }\end{array}$ & $\begin{array}{l}\text { Temperature } \\
\left({ }^{\circ} \mathrm{C}\right)\end{array}$ & $\begin{array}{l}\text { Pressure } \\
\text { (bar) }\end{array}$ & $\begin{array}{l}\text { Butenes selectivity } \\
\text { (\%) }\end{array}$ & Note and Reference \\
\hline \multicolumn{6}{|c|}{ Homogeneous Catalyst } \\
\hline 30 & 1678571 & 45 & 10 & 83.8 & 45 \\
\hline 60 & 166000 & r.t. & 30 & 97.1 & 53 \\
\hline 90 & 199125 & 80 & 30 & 73 & 48 \\
\hline 60 & 55500 & 25 & 30 & / & 54 \\
\hline 40 & 25600 & 30 & 20 & 89.2 & 49 \\
\hline 20 & 51233 & 30 & 20 & 91.5 & 47 \\
\hline 15 & 171428 & 35 & 2 & 90.2 & 33 \\
\hline 60 & 277143 & 45 & 20 & 74 & 35 \\
\hline 30 & 4154464 & 30 & 5.5 & 83 & 50 \\
\hline 30 & 828750 & 30 & 1.3 & 88 & 50 \\
\hline 30 & 167500 & 45 & 28 & 77 & 52 \\
\hline 15 & 107410 & 45 & 10 & 83 & 51 \\
\hline 30 & 16607 & 30 & 2.9 & 95.5 & 34 \\
\hline 30 & 16779 & 30 & 2.9 & 89.8 & 42 \\
\hline 15 & 171428 & 35 & 2 & 90.2 & 43 \\
\hline 45 & 58661 & 45 & 10 & 92.5 & 44 \\
\hline \multicolumn{6}{|c|}{ Heterogeneous Catalyst } \\
\hline 180 & 18446 & 10 & 15 & / & MIL-101 16 \\
\hline 2880 & 400000 & 25 & 50 & 87.6 & CFA-1 ${ }^{18}$ \\
\hline 60 & 41500 & 25 & 50 & 97.4 & MFU-4I ${ }^{17}$ \\
\hline 180 & 18180 & 21 & 15 & $\sim 94$ & NU-1000 29 \\
\hline 240 & 18214 & 25 & 10 & $>71.4$ & UMOFN 19 \\
\hline 120 & 281 & 50 & 15 & 54 & IL-PON-RT 46 \\
\hline 120 & 151 & 50 & 15 & 70 & meso-CTF 46 \\
\hline 240 & 1172800 & 35 & 30 & 88.6 & This work \\
\hline
\end{tabular}

a Derived from the reported average TOF and reaction duration, when a specific "turnover number" value is not available in the literature. 
Table S4. ICP-OES elemental analysis results of Ni-ZIF-8 before (fresh catalyst) and after reaction (used catalyst).

\begin{tabular}{ccccc}
\hline & Samples & Ni amount & Zn amount & Ni/Zn \\
\hline Set 1 & Fresh Ni-ZIF-8 & 0.70 wt\% & 24.40 wt\% & 0.0287 \\
& Used catalyst & 0.47 wt\% & 16.60 wt\% & 0.0283 \\
\multirow{2}{*}{ Set 2 } & Fresh Ni-ZIF-8 & 0.65 wt\% & 22.50 wt\% & 0.0289 \\
& Used catalyst & $0.48 w t \%$ & 16.57 wt\% & 0.0290 \\
\hline
\end{tabular}

Note: The used catalyst has lower contents of $\mathrm{Ni}$ and $\mathrm{Zn}$ than the fresh catalyst, because of the presence of additional Al species produced from the decomposition of the co-catalyst, MAO. The Ni/Zn ratio before and after the reaction is almost constant, indicating that there was no leaching of nickel or decomposition of the catalyst. This conclusion is confirmed by two sets of measurements. 
Table S5. Theoretically predicted mass spectrometry results based on Cossee-Arlman mechanism and Metallacycle mechanism.

\begin{tabular}{|c|c|c|c|c|c|c|c|c|c|c|c|}
\hline \multirow[b]{3}{*}{$\mathrm{m} / \mathrm{z}$} & \multicolumn{7}{|c|}{ Isotopomer } & \multirow{2}{*}{\multicolumn{2}{|c|}{$\begin{array}{c}\text { Cossee- Arlman } \\
1 * \mathrm{C}_{4} \mathrm{H}_{8}+1 * \mathrm{C}_{4} \mathrm{H}_{7} \mathrm{D}+1 * \mathrm{C}_{4} \mathrm{H}_{5} \mathrm{D}_{3}+2 * \mathrm{C}_{4} \mathrm{H}_{4} \mathrm{D}_{4} \\
+1 * \mathrm{C}_{4} \mathrm{D}_{5} \mathrm{H}_{3}+1 * \mathrm{C}_{4} \mathrm{D}_{7} \mathrm{H}+1 * \mathrm{C}_{4} \mathrm{D}_{8}\end{array}$}} & \multirow{2}{*}{\multicolumn{2}{|c|}{$\frac{\text { Metallacycle }}{1 * \mathrm{C}_{4} \mathrm{H}_{8}+2 * \mathrm{C}_{4} \mathrm{H}_{4} \mathrm{D}_{4}+1 * \mathrm{C}_{4} \mathrm{D}_{8}}$}} \\
\hline & $\mathrm{C}_{4} \mathrm{H}_{8}$ & $\mathrm{C}_{4} \mathrm{H}_{7} \mathrm{D}$ & $\mathrm{C}_{4} \mathrm{H}_{5} \mathrm{D}_{3}$ & $\mathrm{C}_{4} \mathrm{HD}_{4}$ & $\mathrm{C}_{4} \mathrm{D}_{5} \mathrm{H}_{3}$ & $\mathrm{C}_{4} \mathrm{D}_{7} \mathrm{H}$ & $\mathrm{CD}_{4}$ & & & & \\
\hline & \multicolumn{7}{|c|}{ Intensity (\%) } & $\begin{array}{c}\text { Sum of } \\
\text { intensity (\%) }\end{array}$ & $\begin{array}{l}\text { Normalized intensity } \\
\text { (\%) }\end{array}$ & $\begin{array}{c}\text { Sum of } \\
\text { intensity (\%) }\end{array}$ & $\begin{array}{l}\text { Normalized } \\
\text { intensity (\%) }\end{array}$ \\
\hline 64 & 0 & 0 & 0 & 0 & 0 & 4.34 & 100 & 104.34 & 45.52 & 100 & 48.96 \\
\hline 63 & 0 & 0 & 0 & 0 & 0 & 100 & 0 & 100 & 43.58 & 0 & 0 \\
\hline 62 & 0 & 0 & 0 & 0 & 4.34 & 5.42 & 43.38 & 53.14 & 22.59 & 43.38 & 21.24 \\
\hline 61 & 0 & 0 & 0 & 4.34 & 100 & 37.98 & 0 & 146.66 & 64.48 & 8.68 & 4.25 \\
\hline 0 & 0 & 0 & 4.34 & 100 & 16.28 & 1.07 & 4.26 & 225.95 & 100 & 204.26 & 100 \\
\hline 59 & 0 & 0 & 100 & 21.69 & 27.58 & 3.23 & 0 & 174.19 & 76.81 & 43.38 & 21.24 \\
\hline 58 & 0 & 4.34 & 27.12 & 22.60 & 2.50 & 4.27 & 11.36 & 94.79 & 41.24 & 56.56 & 27.69 \\
\hline 57 & 4.34 & 100 & 17.82 & 3.24 & 4.59 & 7.13 & 0 & 140.36 & 61.66 & 10.82 & 5.30 \\
\hline 56 & 100 & 37.98 & 4.34 & 5.82 & 6.29 & 1.30 & 2.48 & 164.03 & 72.26 & 114.12 & 55.87 \\
\hline 55 & 43.38 & 8.65 & 6.75 & 5.44 & 3.11 & 1.20 & 0 & 73.97 & 31.92 & 54.26 & 26.56 \\
\hline 54 & 4.26 & 8.20 & 4.27 & 2.70 & 2.59 & 5.31 & 8.52 & 38.55 & 16.05 & 18.18 & 8.90 \\
\hline 53 & 11.36 & 5.47 & 3.55 & 4.22 & 4.73 & 3.19 & 0 & 36.74 & 15.24 & 19.8 & 9.69 \\
\hline 52 & 2.48 & 4.49 & 5.75 & 5.72 & 5.67 & 7.13 & 9.45 & 46.41 & 19.57 & 23.37 & 11.44 \\
\hline 51 & 8.52 & 7.68 & 6.61 & 6.01 & 5.24 & 2.37 & 0 & 42.44 & 17.79 & 20.54 & 10.06 \\
\hline 50 & 9.45 & 7.47 & 4.40 & 3.38 & 2.71 & 2.36 & 2.70 & 35.85 & 14.84 & 18.91 & 9.26 \\
\hline 49 & 2.70 & 2.36 & 1.69 & 1.35 & 1.01 & 0.34 & 0 & 10.8 & 3.62 & 5.4 & 2.64 \\
\hline 48 & 0.34 & 0.34 & 0.34 & 0.34 & 0.34 & 0.34 & 0.34 & 2.72 & 1.21 & 1.36 & 0.67 \\
\hline
\end{tabular}

Note: The intensity values of $\mathrm{C}_{4} \mathrm{H}_{8}$ were obtained experimentally (Figure S14). The intensity values of other isotopomers were calculated based on the fragmentation pattern of $\mathrm{C}_{4} \mathrm{H}_{8}$ (Figure S15). Theoretically, if the reaction proceeds via the Cossee-Arlman mechanism, the produced 1-butene isotopomers should consist of $\mathrm{C}_{4} \mathrm{H}_{8^{\prime}} \mathrm{C}_{4} \mathrm{H}_{7} \mathrm{D}, \mathrm{C}_{4} \mathrm{H}_{5} \mathrm{D}_{3^{\prime}}, \mathrm{C}_{4} \mathrm{H}_{4} \mathrm{D}_{4^{\prime}} \mathrm{C}_{4} \mathrm{H}_{3} \mathrm{D}_{5^{\prime}}$ $\mathrm{C}_{4} \mathrm{HD}_{7}$, and $\mathrm{C}_{4} \mathrm{D}_{8}$ in a 1:1:1:2:1:1:1 ratio; if the reaction proceeds via the metallacycle mechanism, the product should consist of $\mathrm{C}_{4} \mathrm{H}_{8}, \mathrm{C}_{4} \mathrm{H}_{4} \mathrm{D}_{4}$, and $\mathrm{C}_{4} \mathrm{D}_{8}$ in a 1:2:1 ratio. For each mechanism, we summed the intensity values for each $\mathrm{m} / \mathrm{z}$ based on the corresponding isotopomer ratio (sum of intensity) and performed proportional normalization to get "normalized intensity" values, which are used for comparison with the experimental data (see Figure 5). 


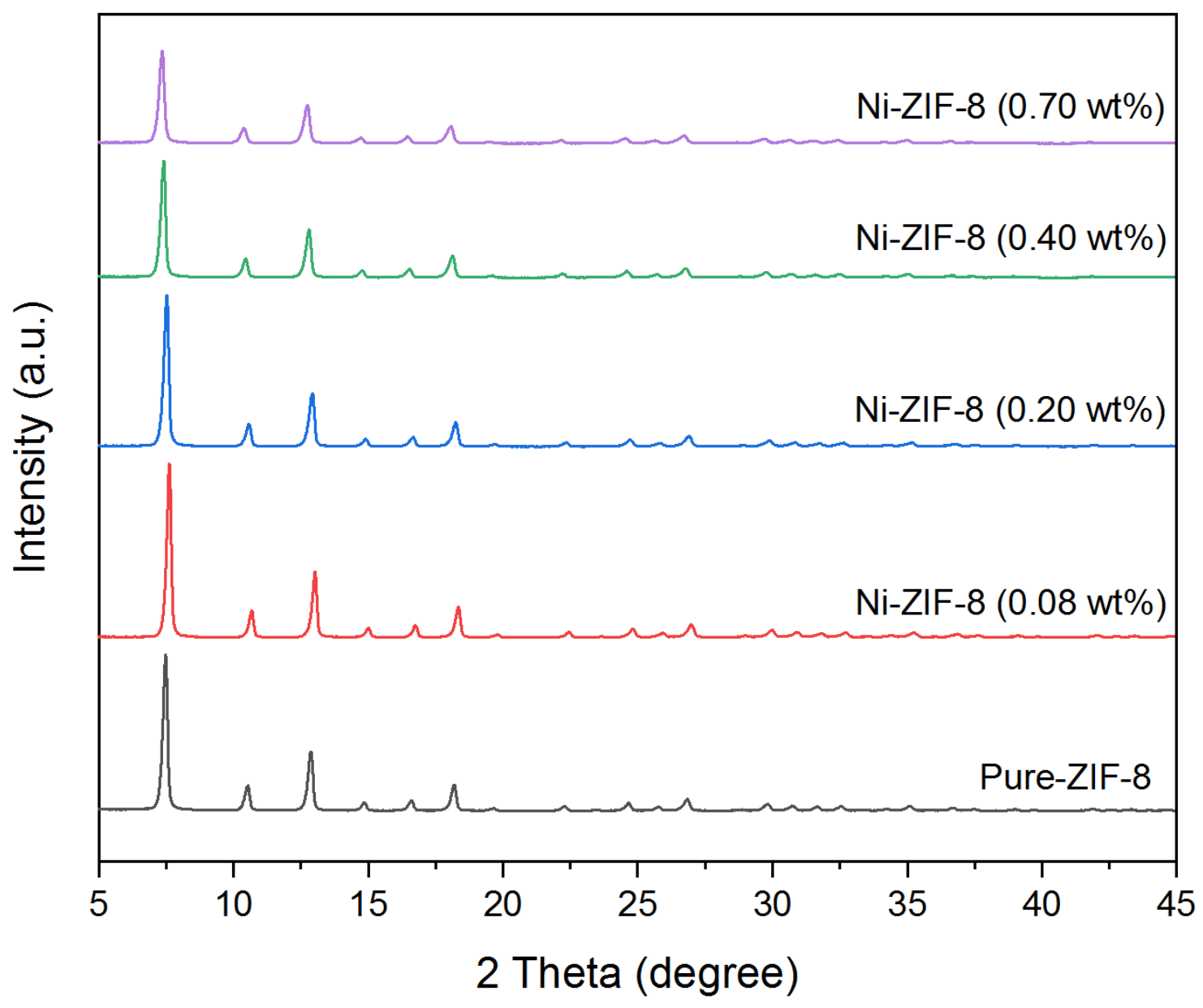

Figure S1. Powder XRD patterns of pure ZIF-8 and Ni-ZIF-8 samples with different Ni loadings. 

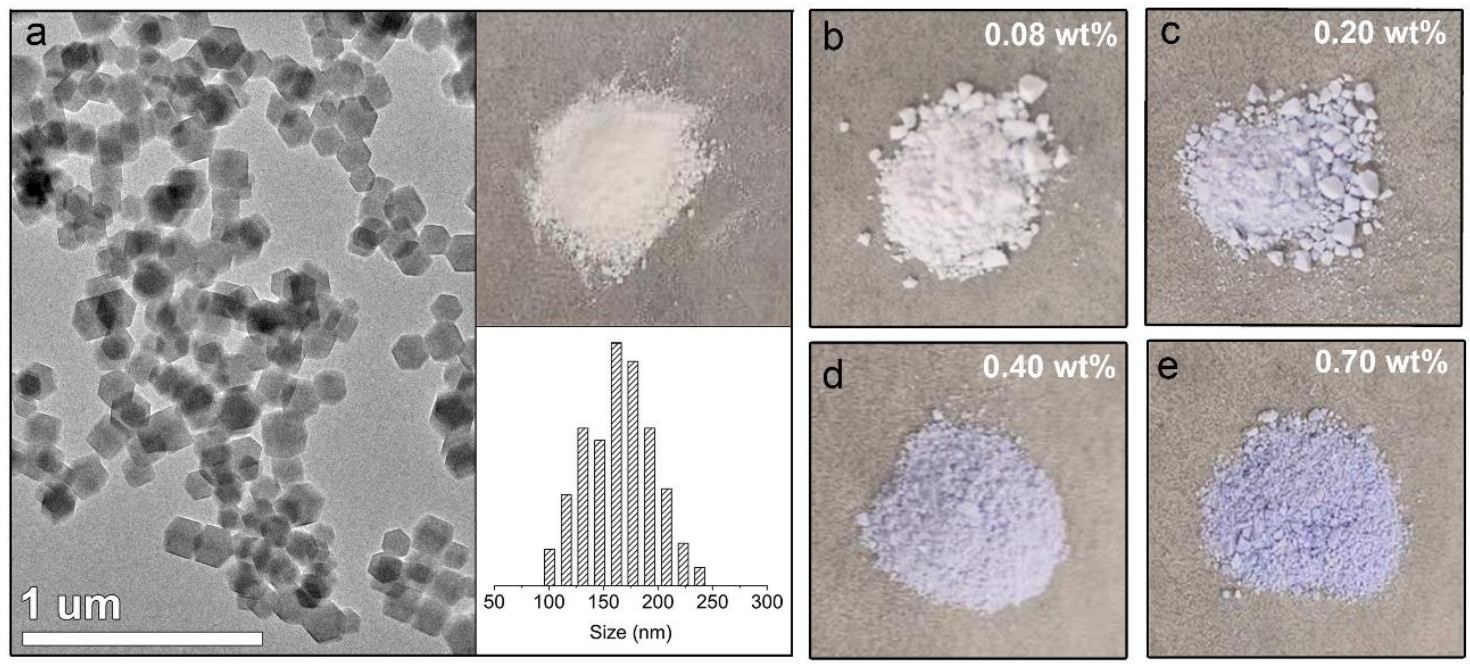

Figure S2. (a) Low-magnification TEM image, photo picture taken under natural light, and size distribution of pure ZIF-8 synthesized from the same conditions as used for Ni-ZIF-8 samples. (b-d) Photo pictures of $\mathrm{Ni}$-ZIF-8 samples with different Ni loadings, showing the gradual deepening of the purple color of Ni-ZIF8 with the increase of $\mathrm{Ni}$ content. 


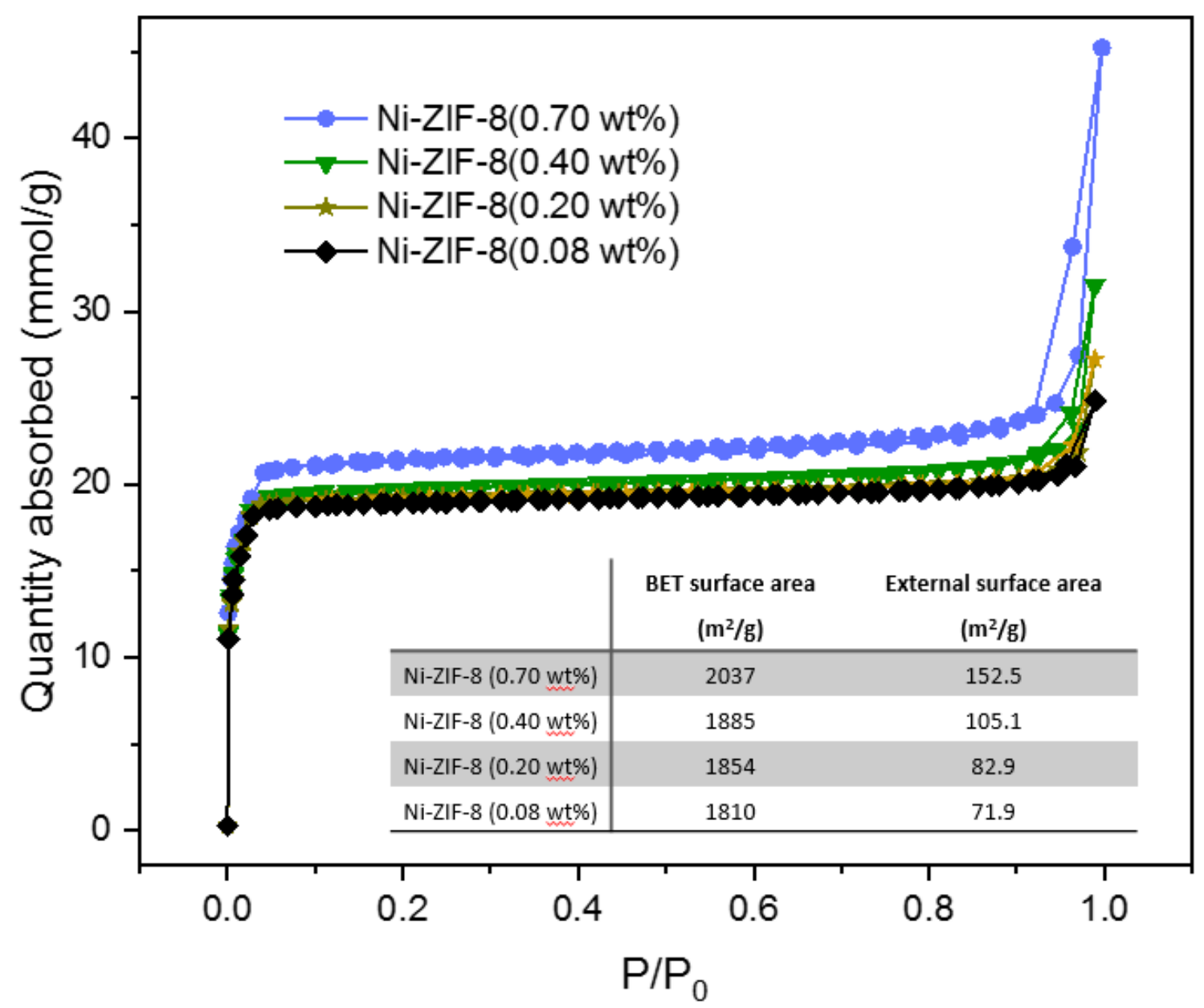

Figure S3. $\mathrm{N}_{2}$ sorption isotherms of Ni-ZIF-8 samples with different Ni loadings collected at $77 \mathrm{~K}$. The inset table presents their BET surface areas and the external surface areas derived from the t-plot method. 

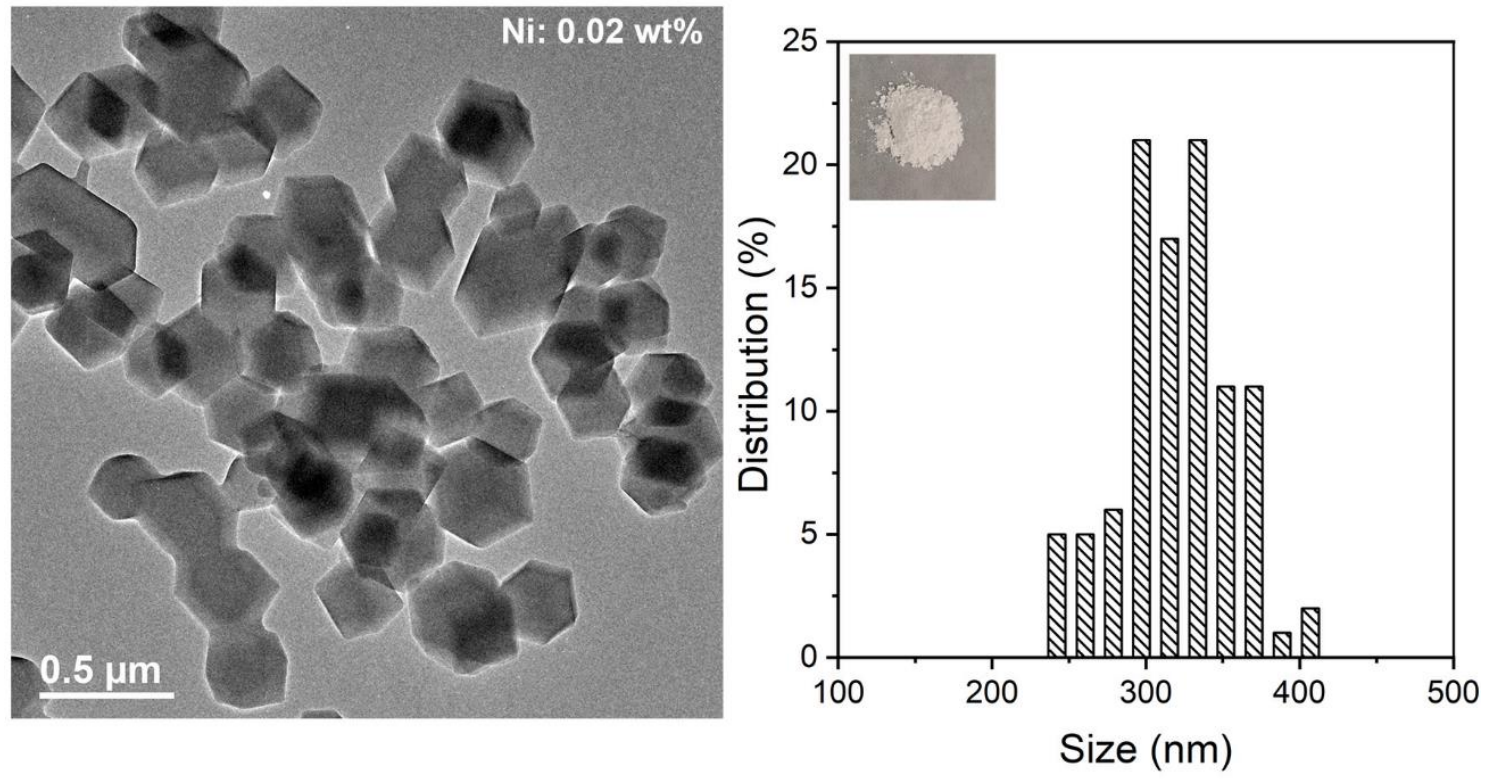

Figure S4. TEM image, crystal size distribution, and photo picture (inset) of a Ni-ZIF-8 sample, which was synthesized by reducing the concentration of 2-methylimidazole by four times relative to the standard synthesis condition used for other samples. Compared to other Ni-ZIF-8 samples, this sample has larger crystal sizes ( $320 \mathrm{~nm}$ ) and lower Ni loading (0.02 wt\%). This result further confirms the correlation between the crystal size and the Ni loading. 


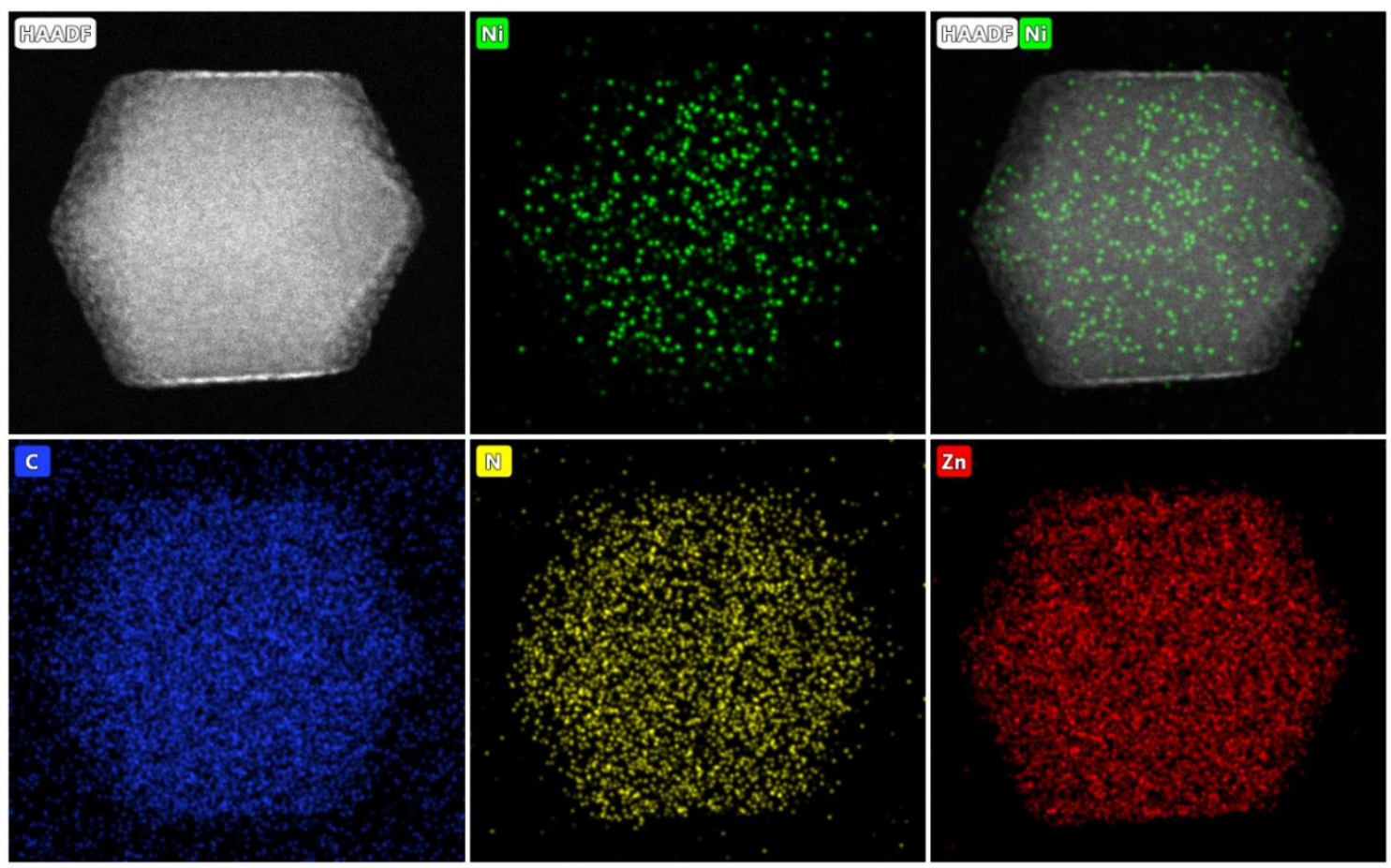

Figure S5. HAADF-STEM image and energy-dispersive X-ray spectroscopy elemental mapping of a Ni-ZIF8 crystal from the sample containing $0.70 \mathrm{wt} \% \mathrm{Ni}$. 


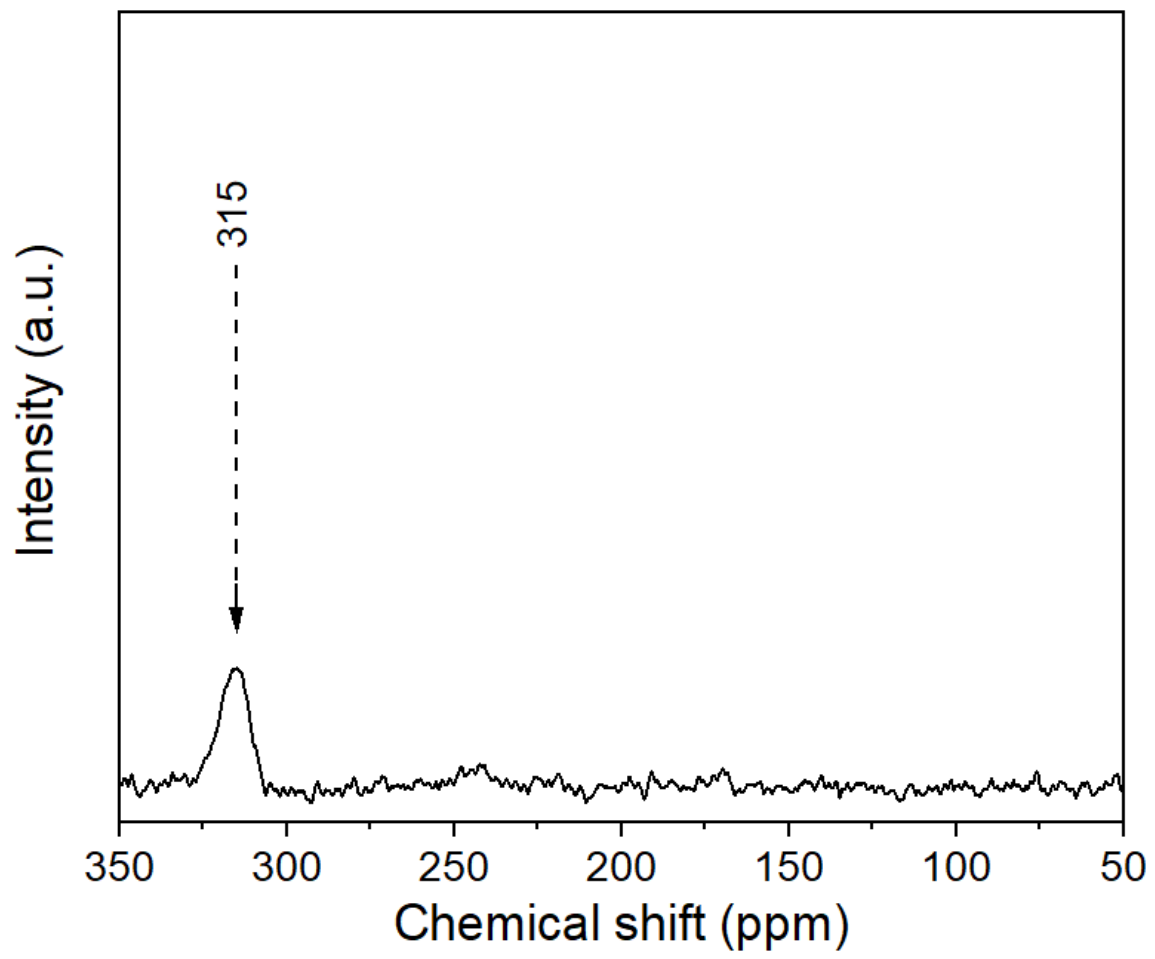

Figure S6. ${ }^{15} \mathrm{~N} \mathrm{CP} / \mathrm{MAS} \mathrm{NMR}$ spectrum of $\mathrm{Ni}\left(\mathrm{NO}_{3}\right)_{2} \cdot 6 \mathrm{H}_{2} \mathrm{O}$. This result validates the assignment of the peak at $315 \mathrm{ppm}$ in the spectrum of Ni-ZIF-8 to the nitrate group. 

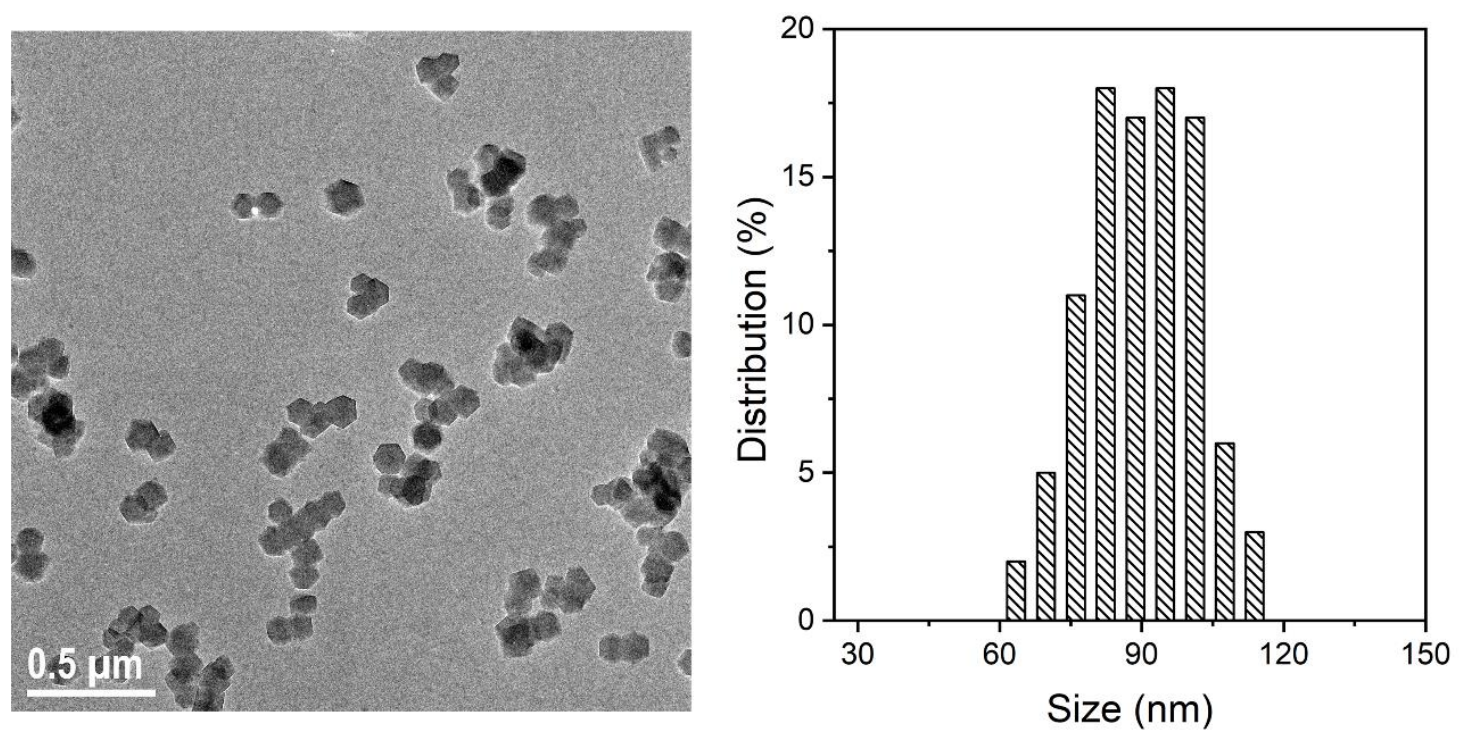

Figure S7. TEM image and crystal size distribution of the core-shell structured sample, Ni-ZIF-8@ZIF-8. The results show that coating Ni-ZIF-8 with a Ni-free ZIF-8 shell increases the average crystal size from 67 $\mathrm{nm}$ to $90 \mathrm{~nm}$. 


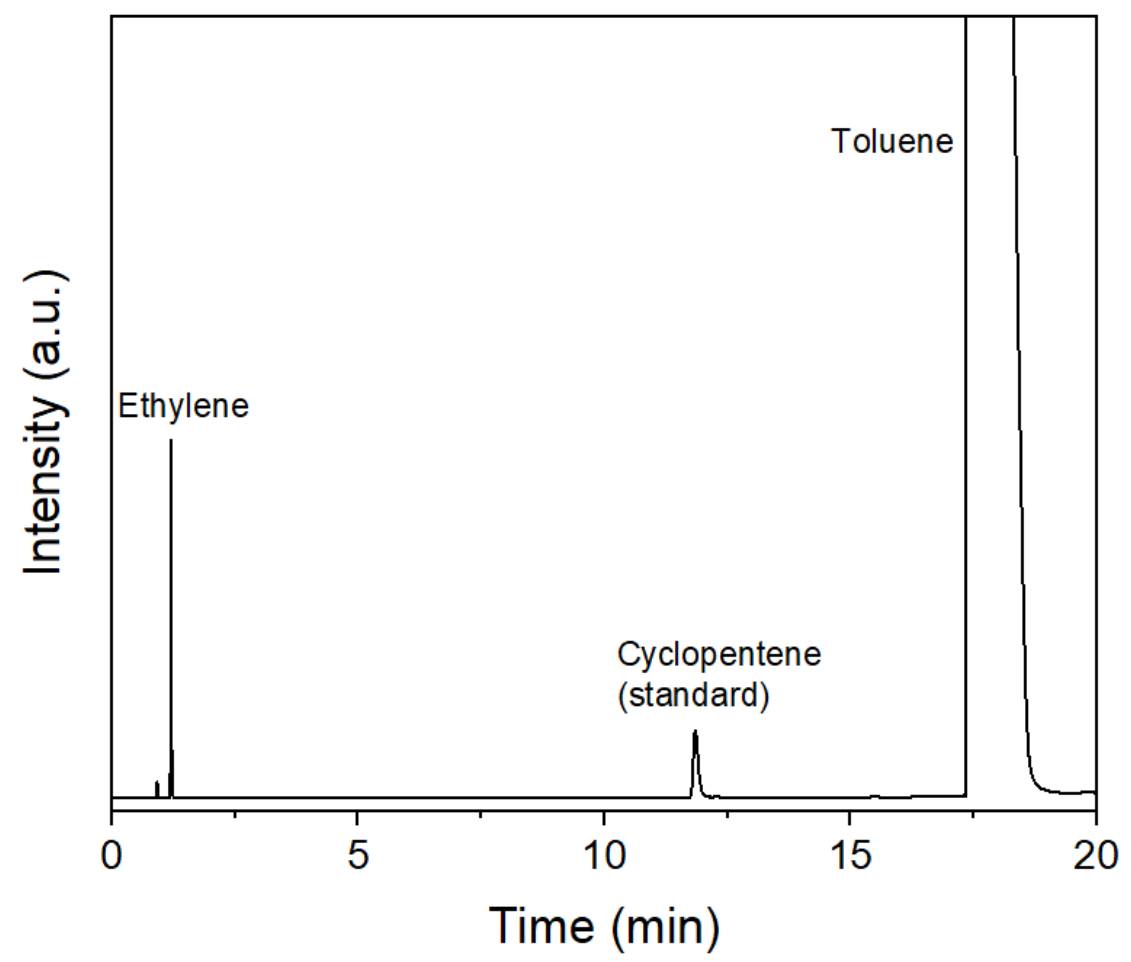

Figure 58. Gas Chromatography record of ethylene dimerization reaction on pure (Ni-free) ZIF-8, indicating that there is no conversion of ethylene. 


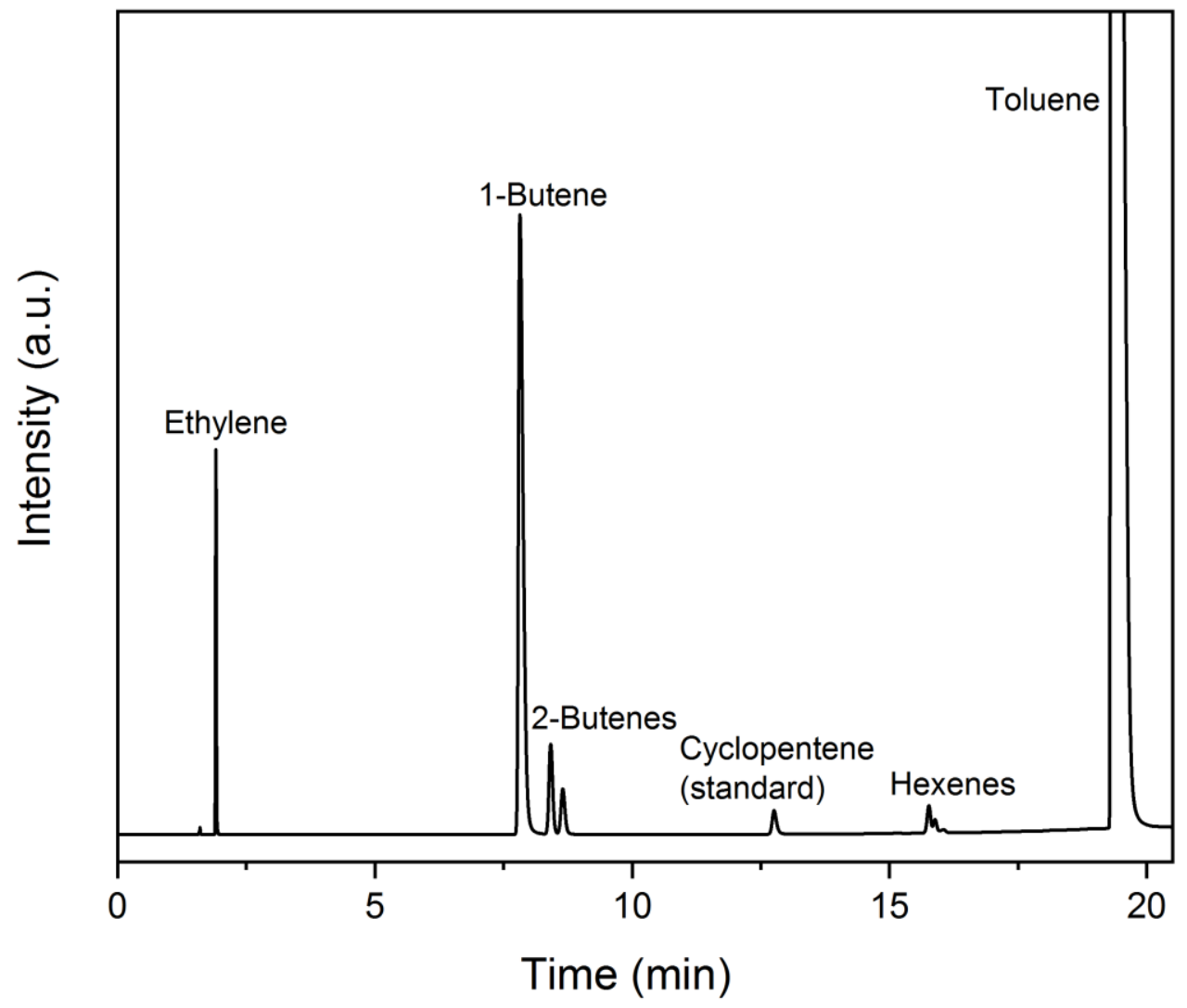

Figure S9. A typical Gas Chromatography record of ethylene dimerization reaction on a Ni-ZIF-8 (0.70wt\%) catalyst, showing a high selectivity to 1-butene. 


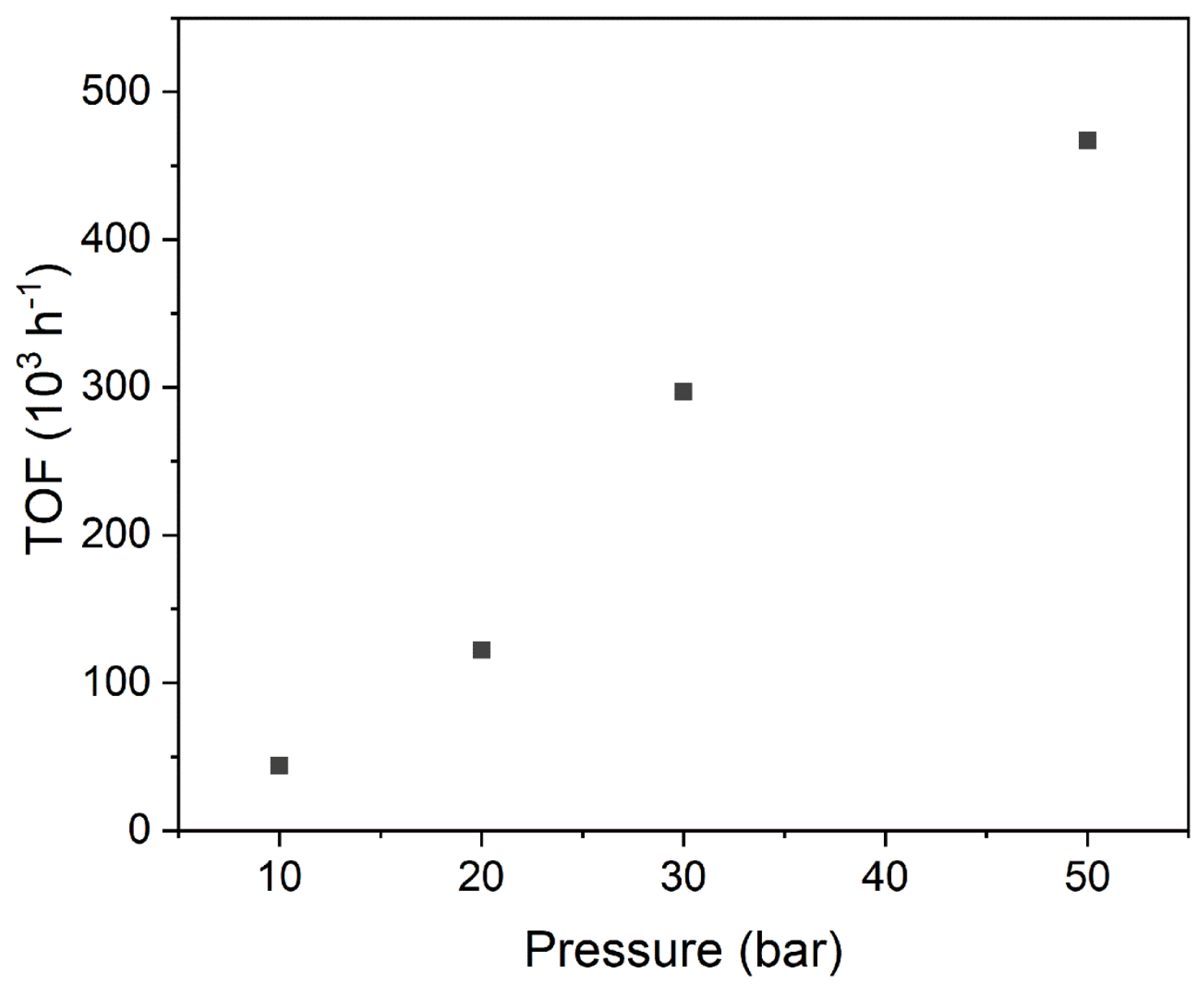

Figure S10. Ethylene dimerization on Ni-ZIF-8 at different ethylene pressures (see entries 5, 12, 13 and 14 in Table 1, for specific reaction conditions). The results show that the TOF linearly increased with the increase in ethylene pressure in the range of 10 to 50 bar, indicating a first-order kinetics behavior. 


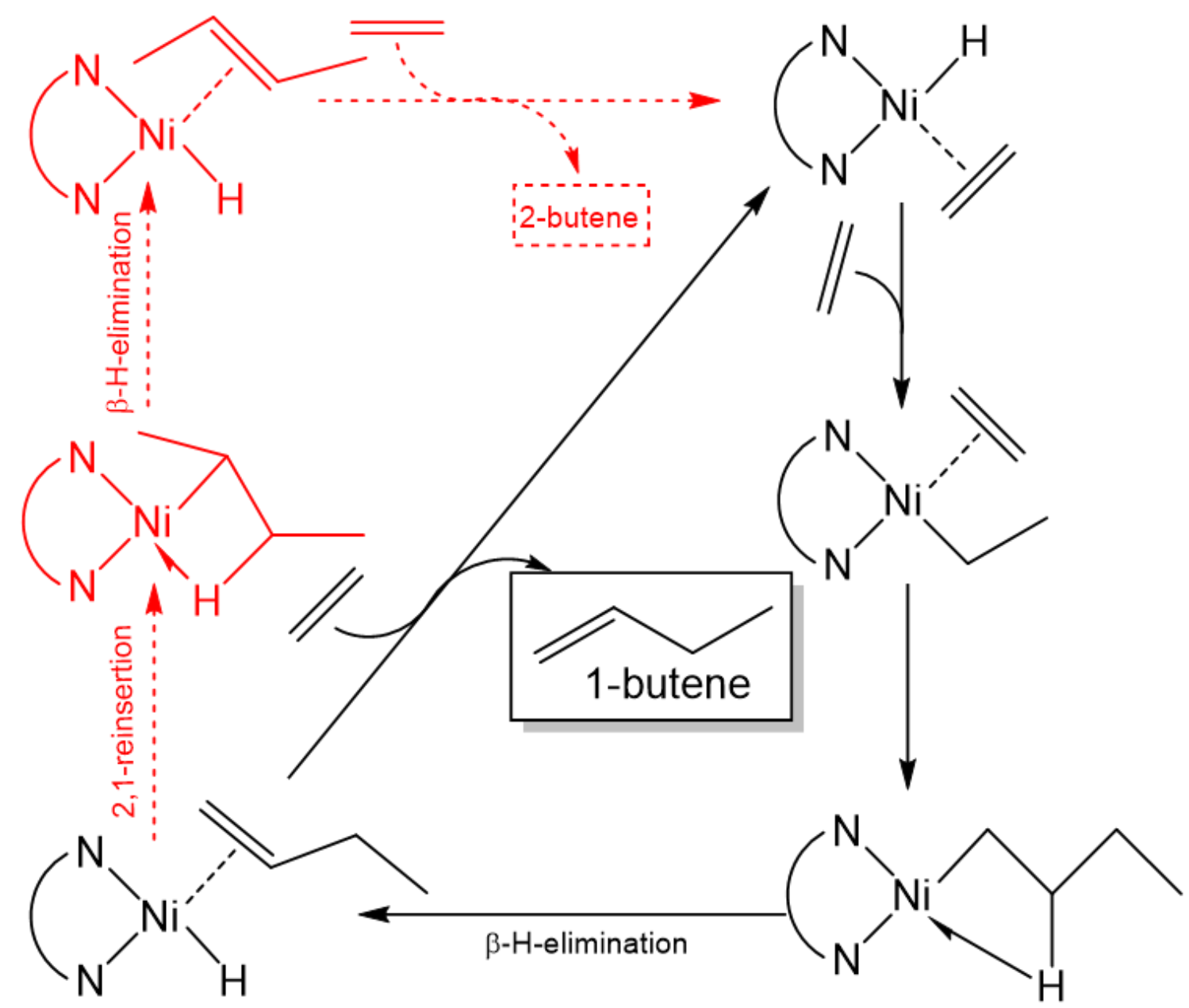

Figure S11. Reaction scheme of ethylene dimerization and 1-butene isomerization on Ni-ZIF-8. The isomerization of 1-butene to 2-butene becomes pronounced at the later stage of the reaction when the concentration of 1-butene in the system is high, which takes place via 2,1-reinsertion followed by $\beta-\mathrm{H}$ elimination. 

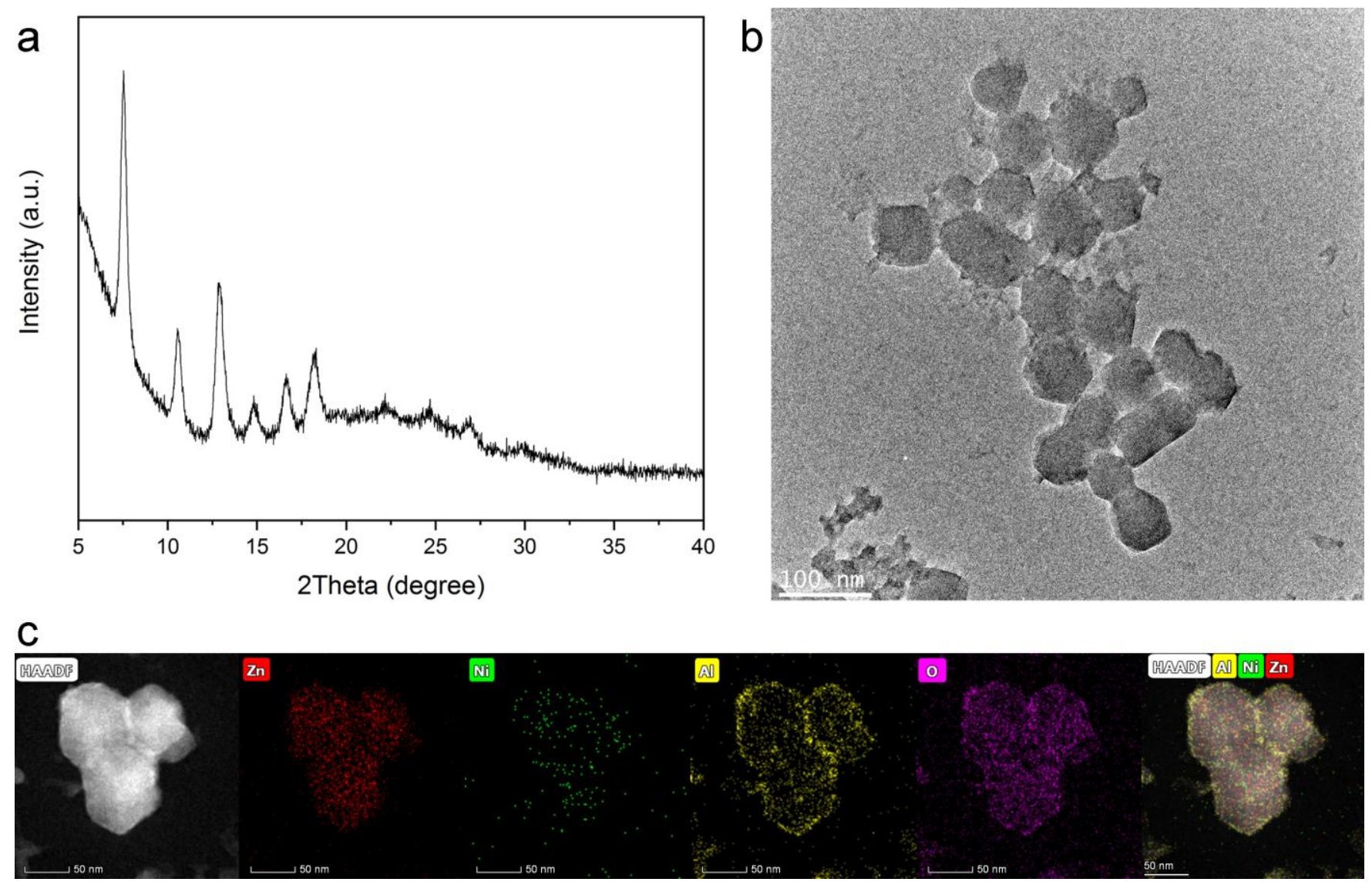

Figure S12. Characterization results of the used Ni-ZIF-8 catalyst: (a) PXRD, (b) TEM, and (c) HAADF-STEM combined with EDS elemental mapping. 


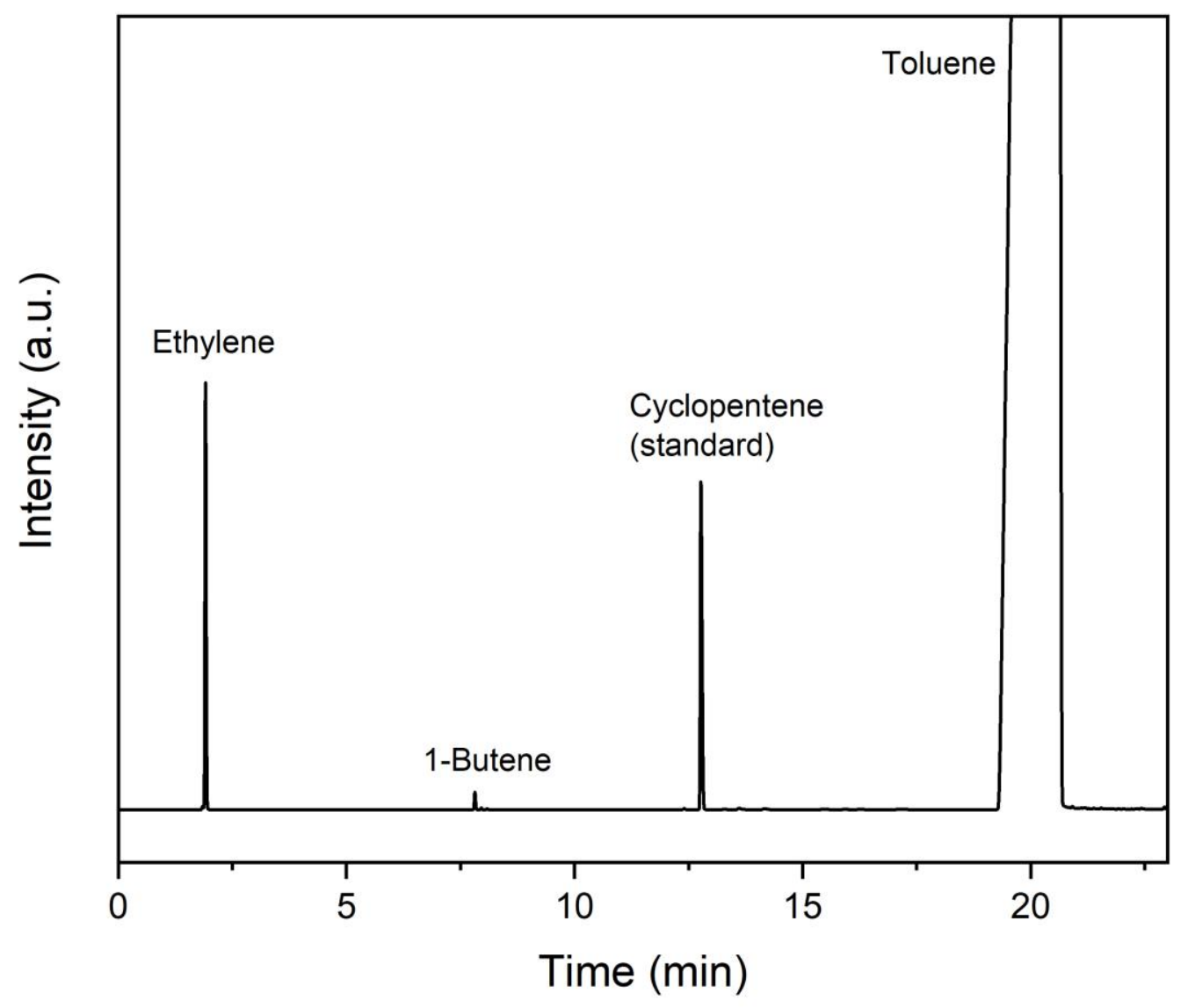

Figure S13. Gas Chromatography record of ethylene dimerization using the supernatant of Ni-ZIF-8/MAO toluene solution as the catalyst. The supernatant was produced and collected as follows. Ni-ZIF-8 catalyst (15 mg) was added into the toluene solution of MAO $(0.075 \mathrm{M})$ in a glovebox, and the solution was stirred at $35^{\circ} \mathrm{C}$ for one hour. Then, the supernatant was separated from the solids by centrifugation and placed into a reactor to perform the ethylene dimerization reaction under the standard reaction conditions (30 bar, $35^{\circ} \mathrm{C}$ ). The result showed that the supernatant was almost inactive, ruling out the possibility that the observed high catalytic activity of Ni-ZIF-8 comes from dissolved species in solution. 


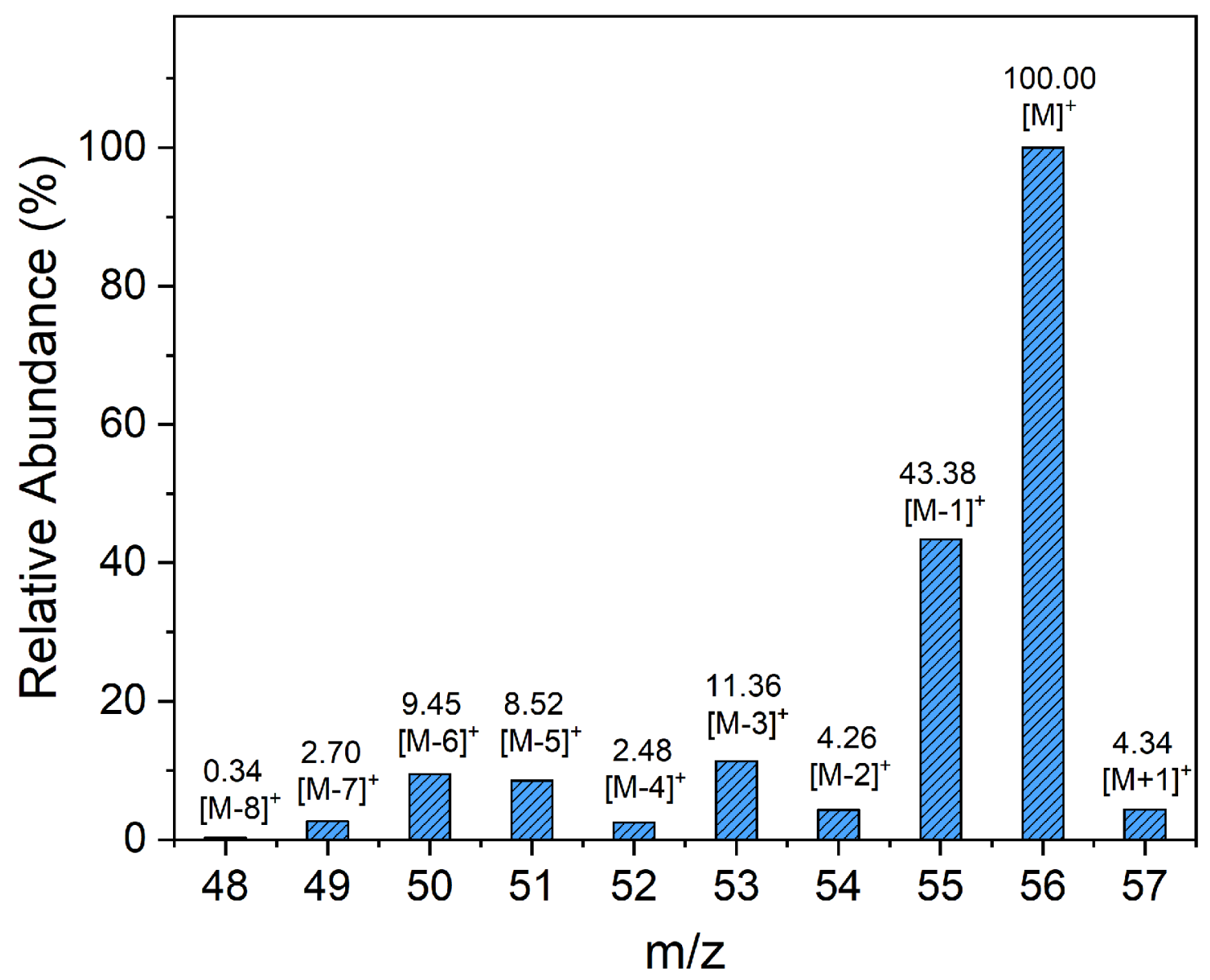

Figure S14. (a) The fragmentation pattern of 1-butene $\left(\mathrm{C}_{4} \mathrm{H}_{8}\right)$. Each peak is labelled with its relative intensity relative to $[M]^{+}(m / z=56)$. $[M-x]^{+}$corresponds to the molecular fragment that loses $x(x=1-8)$ hydrogens. The $[\mathrm{M}+1]^{+}$signal with a relative intensity of $4.34 \%$ arises from the natural abundance of ${ }^{13} \mathrm{C}$. The fragmentation pattern of $\mathrm{C}_{4} \mathrm{H}_{8}$ was used to calculate the theoretical fragmentation patterns of isotope-labelled butenes. The calculation of the $\mathrm{C}_{4} \mathrm{H}_{4} \mathrm{D}_{4}$ fragmentation based on the fragmentation pattern of $\mathrm{C}_{4} \mathrm{H}_{8}$ is shown in Figure $\mathrm{S} 15$ as an example. 

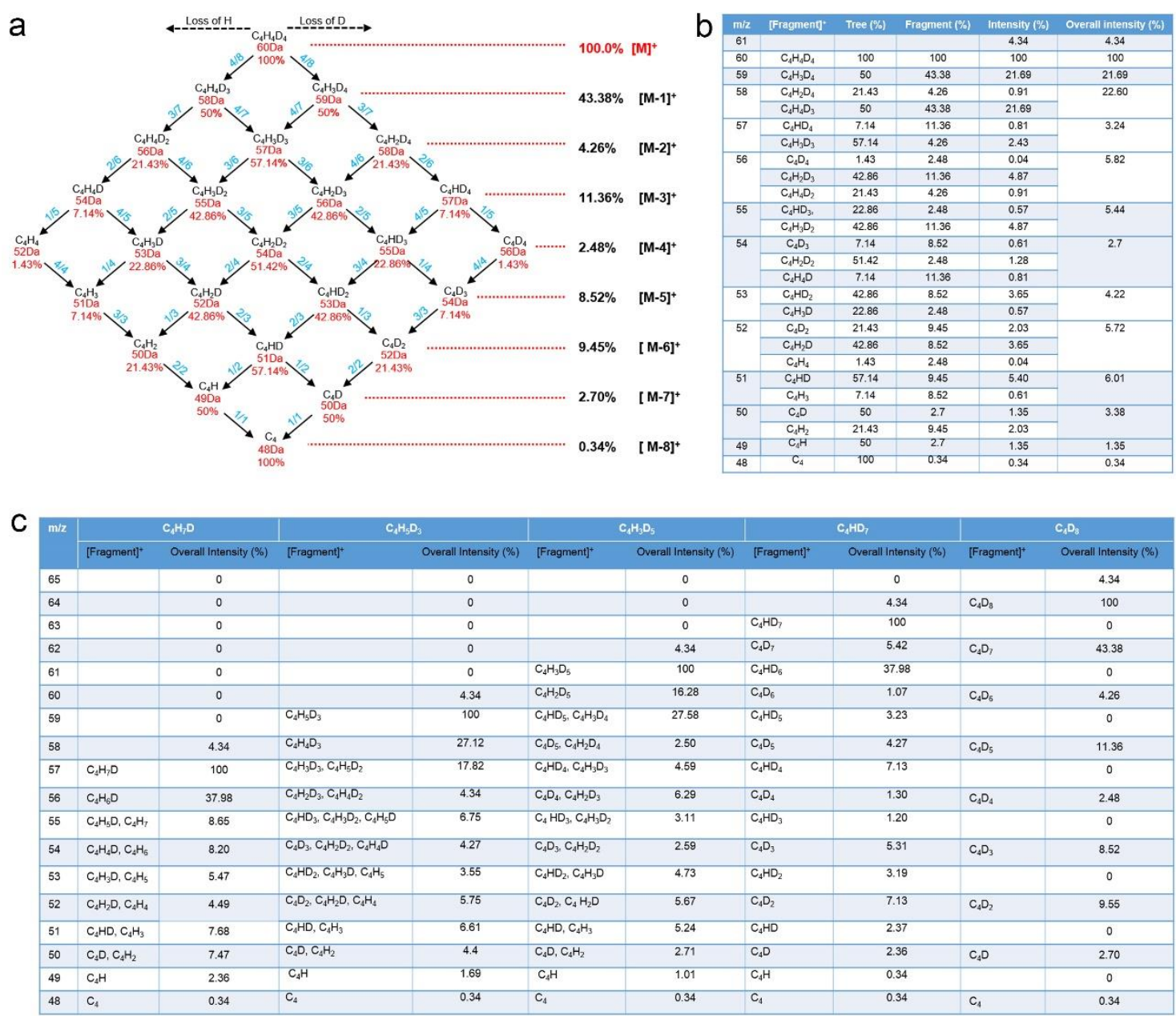

Figure S15. (a) Tree model of $\mathrm{C}_{4} \mathrm{H}_{4} \mathrm{D}_{4}$ fragmentation. Below each fragment are the corresponding $\mathrm{m} / \mathrm{z}$ value and its contribution to the $[\mathrm{M}-\mathrm{x}]^{+}$. The percentages shown on the right are the intensities of each $[M-x]^{+}(x=1-8)$ relative to $[M]^{+}$(from the mass spectrum of $\left.\mathrm{C}_{4} \mathrm{H}_{8}\right)$. (b) Theoretical relative intensity of each fragment in the mass spectrum of $\mathrm{C}_{4} \mathrm{D}_{4} \mathrm{H}_{4}$ calculated based on the tree model and the experimental mass spectrum of $\mathrm{C}_{4} \mathrm{H}_{8}$. (c) Theoretical mass spectra data of $\mathrm{C}_{4} \mathrm{H}_{7} \mathrm{D}, \mathrm{C}_{4} \mathrm{H}_{5} \mathrm{D}_{3}, \mathrm{C}_{4} \mathrm{H}_{3} \mathrm{D}_{5}, \mathrm{C}_{4} \mathrm{HD}_{7}, \mathrm{C}_{4} \mathrm{D}_{8}$, of which the calculation process are similar to that of $\mathrm{C}_{4} \mathrm{H}_{4} \mathrm{D}_{4}$ shown in (a-b). Based on the data shown in this Figure, the theoretical mass spectrometry results for Cossee-ArIman and Metallacycle mechanisms were calculated (see Table S5). 


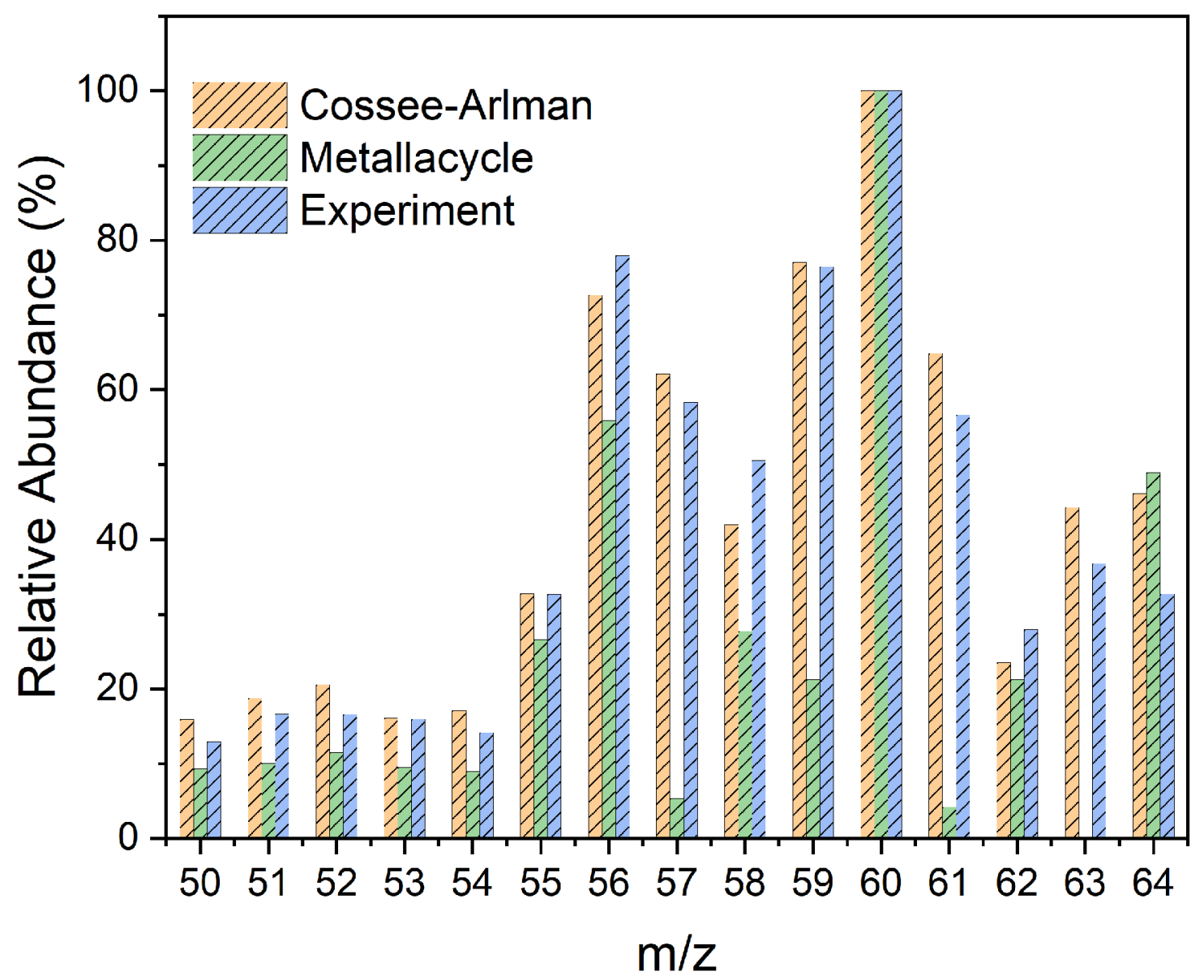

Figure S16. Experimental and predicted fragmentation pattern of 2-butene produced from a mixture of $\mathrm{C}_{2} \mathrm{H}_{4} / \mathrm{C}_{2} \mathrm{D}_{4}$ (1:1). The experimental result show better agreement with the pattern predicted by the Cossee-Arlman mechanism (based on $\mathrm{m} / \mathrm{z}=57,59,61$, and 63 ), consistent with the conclusion drawn from the data of 1-butene (Figure 5). 

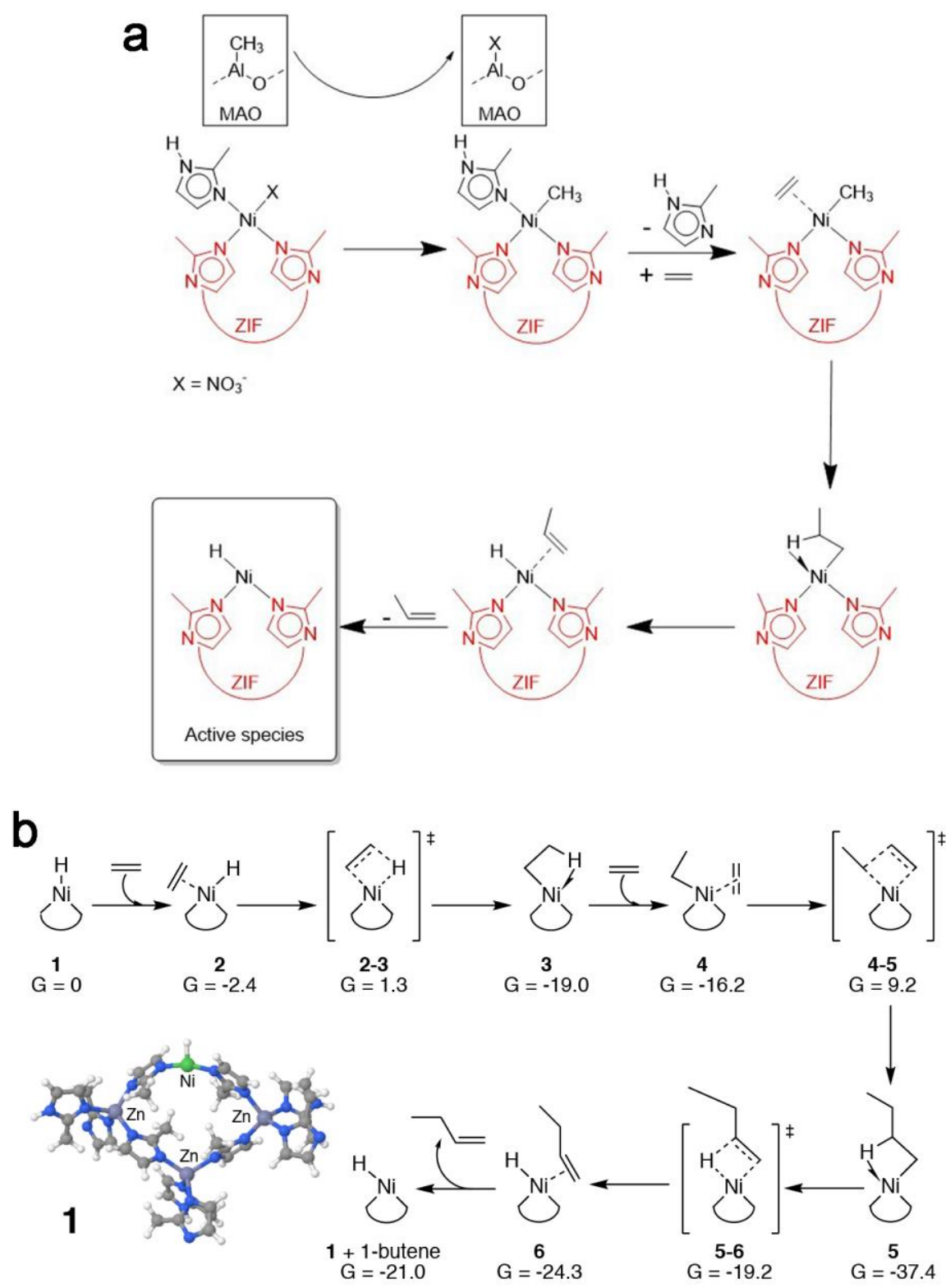

Figure S17. (a) A proposed activation mechanism of Ni-ZIF-8 for ethylene dimerization. (b) Energy profile for ethylene dimerization catalyzed by Ni-ZIF-8. The reaction starts with ethylene coordination to 1 , followed by insertion into the $\mathrm{Ni}-\mathrm{H}$ bond, giving 3 . Coordination of a second ethylene molecule leads to 4, followed by insertion of ethylene insertion into the $\mathrm{Ni}$-ethyl bond via the Cossee-Arlman type transition state 4-5. $\beta$-elimination from 5, liberates 1-butene, and regenerates the starting species 1. Transition states 2-3 and 5-6 were located via a linear scan (see Figure S18), while transition state 4-5 was located with a standard transition state search. The Cartesian coordinates of all these calculated structures in (b) are provided in the last section of the Supporting Information. 


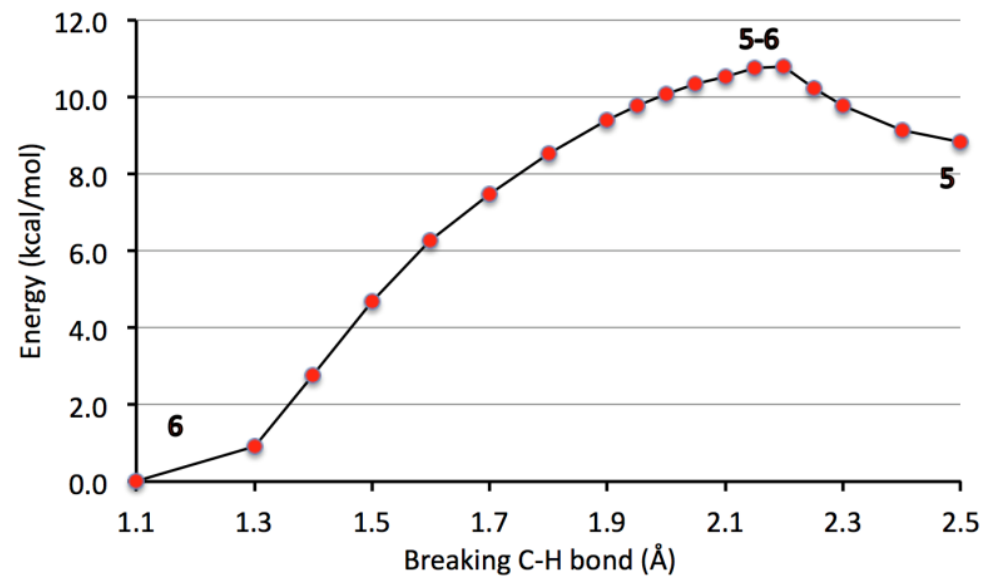

Figure S18. Linear scan on the dissociating C-H distance, connecting 5 to 6 (see Figure S17b). All our attempts to locate a transition state starting from the structure higher in energy in the linear scan, corresponding to a $\mathrm{C}-\mathrm{H}$ distance of $2.20 \AA$, failed. Thus, the top energy structure was taken as an approximation to transition state 5-6. Transition state 2-3 was approximated similarly, by fixing the distance of the emerging $\mathrm{C}-\mathrm{H}$ bond to of $2.20 \AA$. 


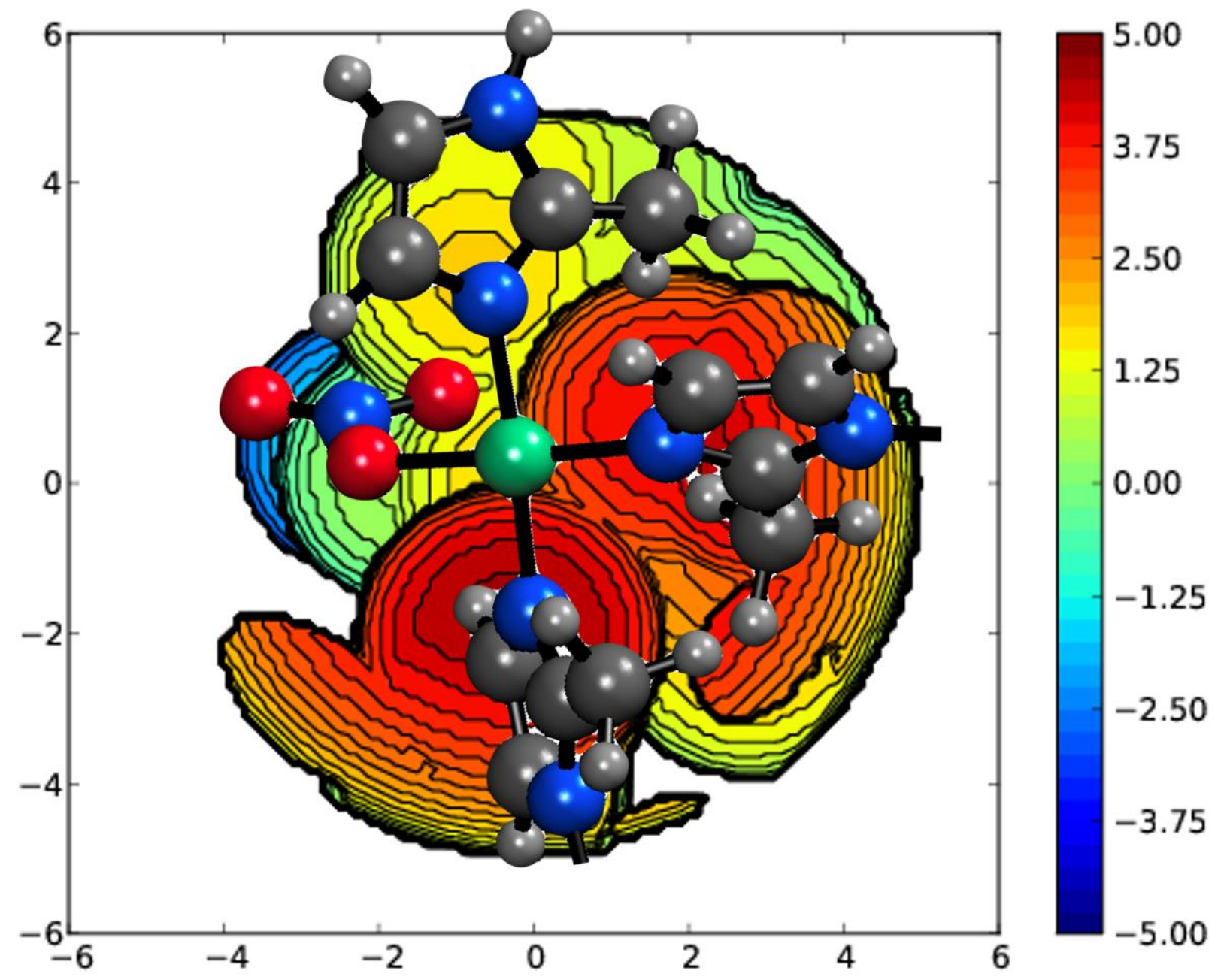

Figure S19. Steric environment of the planar-coordinated $\mathrm{Ni}$ in Ni-ZIF-8. The central $\mathrm{Ni}$ atom is coordinated with four neighboring groups, namely, two imidazolium, one nitrate and one methanol molecule, to form a planar structure. The steric effect of these coordination groups was evaluated by calculated the buried volume within a spherical space with a $5 \dot{A}$ radius centered at $\mathrm{Ni}$. The projected coordination environment is presented in this figure, and the red-to-blue color bar represents the coordinates of surrounding molecules along the $z$ direction. 


\section{References}

S1 Pan, Y. et al. Core-shell ZIF-8@ZIF-67-derived CoP nanoparticle-embedded N-doped carbon nanotube hollow polyhedron for efficient overall water splitting. J. Am. Chem. Soc. 140, 26102618 (2018).

S2 Nagarjun, N. \& Dhakshinamoorthy, A. A Cu-Doped ZIF-8 metal organic framework as a heterogeneous solid catalyst for aerobic oxidation of benzylic hydrocarbons. New J. Chem. 43, 18702-18712 (2019).

S3 Perdew, J. P., Burke, K. \& Ernzerhof, M. Generalized gradient approximation made simple. Phys. Rev. Lett. 77, 3865-3868 (1996).

S4 Grimme, S. et al. A consistent and accurate $a b$ initio parametrization of density functional dispersion correction (DFT-D) for the 94 elements H-Pu. Chem. Phys. 132, 154104 ( 2010)

S5 Frisch, M. J. et al, Gaussian 09, revision D.01 2013, Gaussian Inc., Wallingford, CT.

S6 Schäfer, A., Horn, H. \& Ahlrichs, R. Fully optimized contracted Gaussian basis sets for atoms Li to Kr. J. Chem. Phys. 92, 2571-2577 (1992).

S7 Weigend, F. \& Ahlrichs, R. Balanced basis sets of split valence, triple zeta valence and quadruple zeta valence quality for $\mathrm{H}$ to Rn: design and assessment of accuracy. Phys. Chem. Chem. Phys. 7, 3297-3305 (2005).

S8 Andrae, D. et al. Energy-adjusted ab initio pseudopotentials for the second and third row transition tlements. Theor. Chim. Acta 77, 123-141 (1990). 


\section{Cartesian coordinates of the structure models in Figure S17}

$\begin{array}{ccrr}6 & & \\ \text { Et SCF } & \text { Done: }-78.4138422003 \mathrm{~A} . \mathrm{U} . & \\ \text { C } & 0.000000 & 0.000000 & 0.670193 \\ \text { C } & 0.000000 & 0.000000 & -0.670193 \\ \text { H } & 0.000000 & 0.937666 & 1.249931 \\ \text { H } & 0.000000 & -0.937666 & 1.249931 \\ \text { H } & 0.000000 & 0.937666 & -1.249931 \\ \text { H } & 0.000000 & -0.937666 & -1.249931\end{array}$

12

Bu SCF Done: -156.882119107 A.U.

$\begin{array}{lrrr}\mathrm{C} & -0.720881 & -0.301255 & 0.336573 \\ \mathrm{H} & -0.669961 & -1.253196 & 0.899533 \\ \mathrm{C} & -1.870134 & 0.023903 & -0.279960 \\ \mathrm{H} & -1.966284 & 0.959479 & -0.857034 \\ \mathrm{H} & -2.757687 & -0.626052 & -0.230158 \\ \mathrm{C} & 0.543252 & 0.512110 & 0.317626 \\ \mathrm{H} & 0.364827 & 1.463052 & -0.228572 \\ \mathrm{H} & 0.804585 & 0.797234 & 1.362433 \\ \mathrm{C} & 1.731366 & -0.239066 & -0.300776 \\ \mathrm{H} & 2.656370 & 0.371288 & -0.267382 \\ \mathrm{H} & 1.936008 & -1.186484 & 0.240253 \\ \mathrm{H} & 1.530523 & -0.499468 & -1.359852\end{array}$

118

1.Ni-H SCF Done: -4836.74657489 A.U.

\begin{tabular}{|c|c|c|c|}
\hline $\mathrm{C}$ & 1048327 & $5 \quad 592333$ & 1227543 \\
\hline $\mathrm{C}$ & -7.204428 & -2.172380 & 2.135319 \\
\hline $\mathrm{C}$ & 7.463854 & 0.554365 & 1.538052 \\
\hline 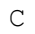 & -1.736833 & 0.051036 & 1.187687 \\
\hline & -0.728472 & 3.789119 & 1.344661 \\
\hline & -7.419237 & 0.227752 & 2.829108 \\
\hline & 7.485398 & -1.458153 & 3.064999 \\
\hline $\mathrm{N}$ & -1.012337 & 5.508867 & 2.682902 \\
\hline & -5.608420 & -0.300752 & 1.571936 \\
\hline & 5.826765 & -1.373766 & 1.628125 \\
\hline & 3.432127 & 0.516116 & 0.434094 \\
\hline 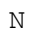 & 1.545773 & 1.717164 & 0.385302 \\
\hline$C$ & -1.912168 & 3.613236 & 2.036955 \\
\hline C & -6.661140 & 1.359529 & 2.632826 \\
\hline $\mathrm{C}$ & 6.755395 & -2.619186 & 3.255110 \\
\hline 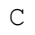 & -2.105776 & 4.684028 & 2.883574 \\
\hline$c$ & -5.546556 & 1.053478 & 1.858433 \\
\hline C & 5.721920 & -2.550145 & 2.344531 \\
\hline C & 3.266982 & 1.097892 & 1.675042 \\
\hline 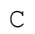 & 2.099751 & 1.842509 & 1.646232 \\
\hline & -0.192499 & 4.952016 & 1.743276 \\
\hline $\mathrm{C}$ & -6.758005 & -0.742617 & 2.181907 \\
\hline C & 6.910219 & -0.720500 & 2.070001 \\
\hline$C$ & -2.241077 & 0.616696 & -0.102240 \\
\hline 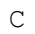 & 2.376026 & 0.909592 & -0.318666 \\
\hline $\mathbb{N}$ & -3.382342 & 0.212899 & -0.71089 \\
\hline & -1.596058 & 1.551657 & -0.843116 \\
\hline & 6.160931 & -0.291135 & -1.322411 \\
\hline N & -6.147084 & -1.523842 & -1.327454 \\
\hline T & 0.434951 & 4.117544 & -1.587448 \\
\hline 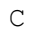 & 2.134252 & 0.463269 & -1.724366 \\
\hline $\mathrm{C}$ & -3.464156 & 0.915370 & -1.89683 \\
\hline $\mathrm{C}$ & -2.358555 & 1.744738 & -1.980832 \\
\hline $\mathrm{C}$ & 6.324003 & 1.018435 & -1.744161 \\
\hline $\mathrm{C}$ & 7.392505 & -0.880028 & -1.495689 \\
\hline & -7.250188 & -0.788652 & -1.52797 \\
\hline C & -6.262557 & -2.674045 & -2.08516 \\
\hline $\mathrm{C}$ & -0.262763 & 5.284354 & -1.80762 \\
\hline C & 1.726029 & 4.385527 & -2.011970 \\
\hline & 7.644901 & 1.152757 & -2.15833 \\
\hline & 8.310508 & -0.041741 & -1.99598 \\
\hline & 7.677450 & -2.306140 & -1.13133 \\
\hline
\end{tabular}

$$
\begin{aligned}
& -8.056834 \\
& -7.597196 \\
& -7.457203 \\
& 0.491130 \\
& -1.705798 \\
& 1.741810 \\
& 4.767389 \\
& -4.669698 \\
& -0.052180 \\
& 3.087420 \\
& 1.473516 \\
& 1.654155 \\
& -2.544695 \\
& -0.908551 \\
& -1.352441 \\
& -7.942745 \\
& -8.389717 \\
& -6.707478 \\
& -8.220416 \\
& -6.539493 \\
& -7.225167 \\
& 8.586961 \\
& 6.839184 \\
& 7.858160 \\
& 0.850007 \\
& 1.810761 \\
& 1.466776 \\
& -2.279297 \\
& -2.162935 \\
& -1.836676 \\
& 8.115681 \\
& 6.647165 \\
& 8.050625 \\
& -6.953007 \\
& -4.741362 \\
& -2.547495 \\
& -2.901794 \\
& -7.920201 \\
& -5.484913 \\
& -4.296786 \\
& -2.053150 \\
& 1.625310 \\
& \text { 3. } 984829 \\
& 5.495064 \\
& 8.141977 \\
& 4.921176 \\
& 7.028369 \\
& -8.965137 \\
& -0.844136 \\
& 8.333668 \\
& 0.069201 \\
& 1.941680 \\
& -3.605260 \\
& -1.711500 \\
& -3.473951 \\
& -2.308726 \\
& \text { 2. } 497154 \\
& -2.530860 \\
& \text { 1. } 842402 \\
& \text { 3. } 662392 \\
& -2.241868 \\
& 2.637413 \\
& 3.759576 \\
& -1.660834 \\
& -1.655041 \\
& -3.177513 \\
& 1.391669 \\
& \text { 2. } 741771 \\
& 1.239947
\end{aligned}
$$




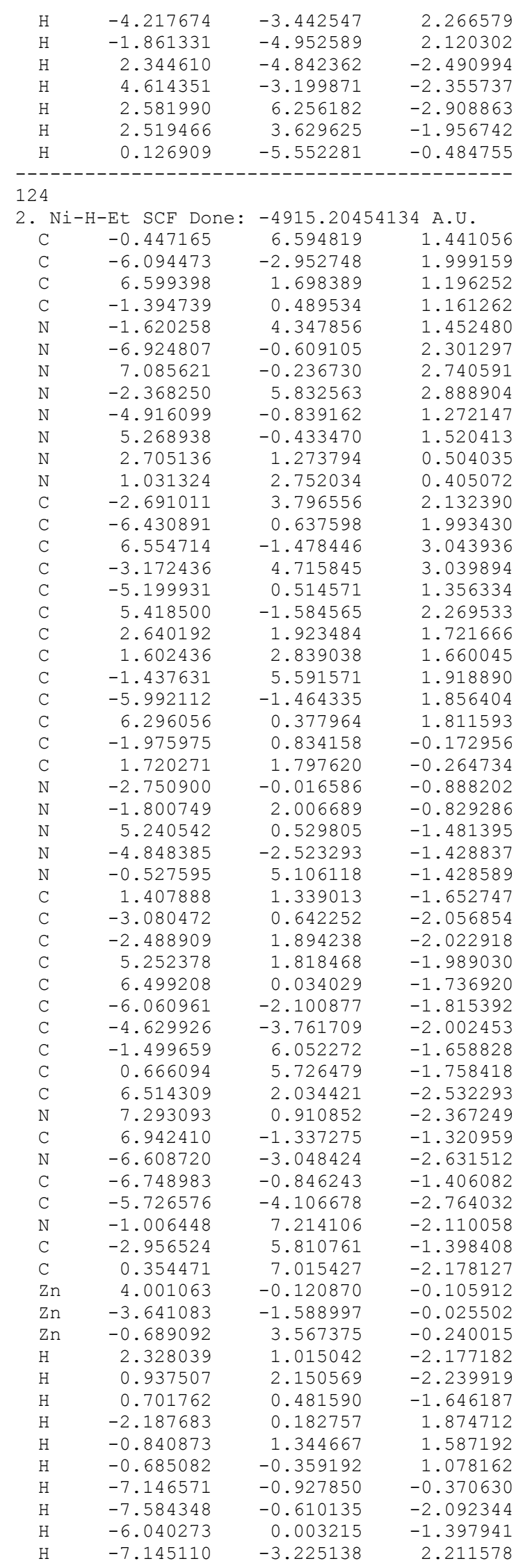

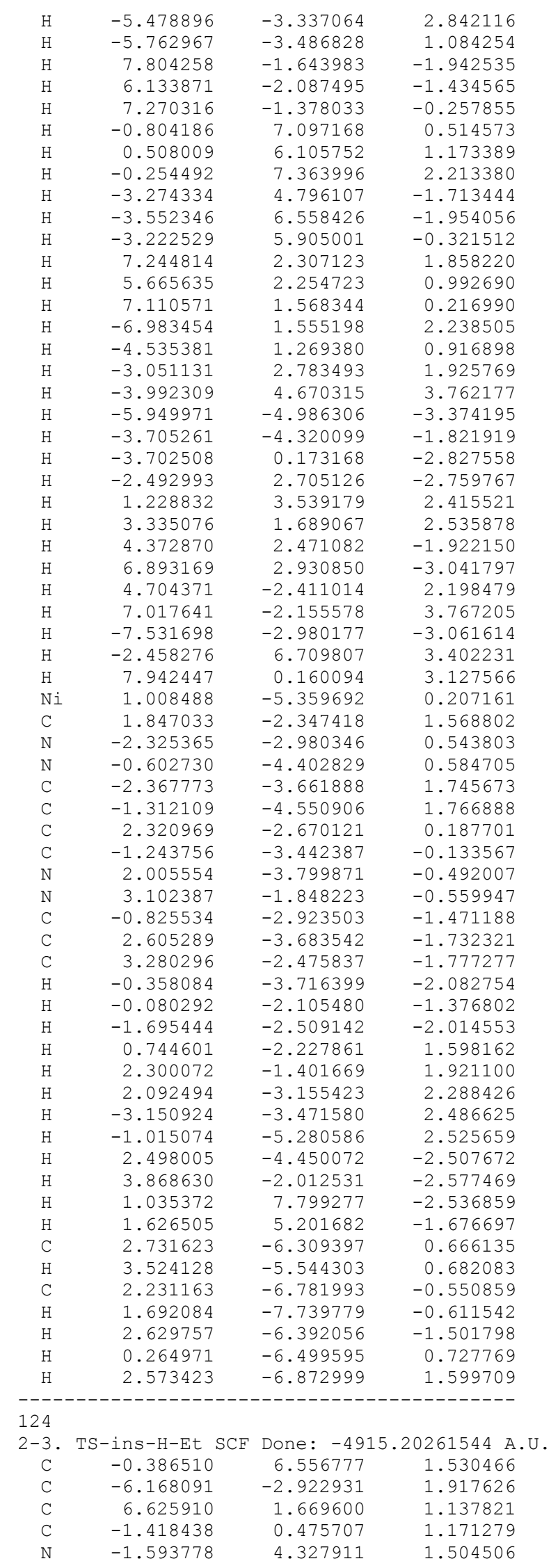




\begin{tabular}{|c|c|c|}
\hline-6.979728 & -0.572965 & 2.221638 \\
\hline 7.151950 & -0.291143 & 2.637267 \\
\hline-2.334195 & 5.808143 & 2.949409 \\
\hline-4.959123 & -0.817106 & 1.219295 \\
\hline 5.314412 & -0.475259 & 1.447120 \\
\hline 2.721479 & 1.237092 & 0.497184 \\
\hline 1.048009 & 2.717711 & 0.433903 \\
\hline-2.680640 & 3.786093 & 2.166278 \\
\hline-6.468913 & 0.670452 & 1.928712 \\
\hline 6.633232 & -1.541457 & 2.926635 \\
\hline-3.157536 & 4.702707 & 3.078862 \\
\hline-5.230301 & 0.538895 & 1.308241 \\
\hline 5.483581 & -1.639408 & 2.171185 \\
\hline 2.672306 & 1.874532 & 1.721937 \\
\hline 1.634621 & 2.791474 & 1.682507 \\
\hline-1.396990 & 5.563379 & 1.986725 \\
\hline-6.049427 & -1.434816 & 1.784438 \\
\hline 6.342151 & 0.336371 & 1.734550 \\
\hline-1.981858 & 0.838163 & -0.165827 \\
\hline 1.727604 & 1.769260 & -0.253942 \\
\hline-2.755221 & 0.001201 & -0.898611 \\
\hline-1.793360 & 2.017522 & -0.805819 \\
\hline 5.222720 & 0.530218 & -1.536232 \\
\hline-4.861666 & -2.481298 & -1.494319 \\
\hline-0.489968 & 5.111366 & -1.360511 \\
\hline 1.398209 & 1.324776 & -1.642634 \\
\hline-3.070264 & 0.676711 & -2.061782 \\
\hline-2.471318 & 1.924457 & -2.006967 \\
\hline 5.215583 & 1.826998 & -2.023178 \\
\hline 6.481153 & 0.049438 & -1.820555 \\
\hline-6.067275 & -2.050865 & -1.893636 \\
\hline-4.636403 & -3.711743 & -2.082172 \\
\hline-1.453318 & 6.069744 & -1.576047 \\
\hline 0.708830 & 5.723795 & -1.686158 \\
\hline 6.466387 & 2.062288 & -2.583693 \\
\hline 7.257057 & 0.943002 & -2.449751 \\
\hline 6.943964 & -1.324265 & -1.434587 \\
\hline-6.604023 & -2.985830 & -2.731364 \\
\hline-6.758760 & -0.799904 & -1.478956 \\
\hline-5.721771 & -4.043827 & -2.865338 \\
\hline-0.950031 & 7.232145 & -2.014481 \\
\hline-2.911406 & 5.839239 & -1.311941 \\
\hline 0.408647 & 7.020833 & -2.089142 \\
\hline 4.012860 & -0.146932 & -0.148118 \\
\hline-3.670354 & -1.571319 & -0.062548 \\
\hline-0.666728 & 3.557613 & -0.193600 \\
\hline 2.310354 & 0.995160 & -2.177360 \\
\hline 0.931812 & 2.145707 & -2.219883 \\
\hline 0.682698 & 0.475110 & -1.636610 \\
\hline-2.223589 & 0.189822 & 1.879921 \\
\hline-0.843913 & 1.315091 & 1.601339 \\
\hline-0.732790 & -0.392685 & 1.091049 \\
\hline-7.169985 & -0.892159 & -0.449714 \\
\hline-7.584610 & -0.554601 & -2.173445 \\
\hline-6.049043 & 0.048351 & -1.451523 \\
\hline-7.226750 & -3.188404 & 2.096671 \\
\hline-5.582279 & -3.315163 & 2.778110 \\
\hline-5.812541 & -3.455781 & 1.011129 \\
\hline 7.781507 & -1.623427 & -2.092215 \\
\hline 6.133988 & -2.076117 & -1.522861 \\
\hline 7.315113 & -1.374067 & -0.386035 \\
\hline-0.728782 & 7.078641 & 0.609306 \\
\hline 0.562387 & 6.055930 & 1.262428 \\
\hline-0.186615 & 7.311294 & 2.315362 \\
\hline-3.230246 & 4.816916 & -1.599374 \\
\hline-3.505911 & 6.572764 & -1.887698 \\
\hline-3.179392 & 5.964054 & -0.238474 \\
\hline 7.277774 & 2.271784 & 1.799446 \\
\hline 5.684727 & 2.222138 & 0.959313 \\
\hline 7.121469 & 1.560626 & 0.148005 \\
\hline-7.015602 & 1.592112 & 2.171736 \\
\hline
\end{tabular}

\begin{tabular}{|c|c|c|c|}
\hline $\mathrm{H}$ & -4.551810 & 1.289665 & 0.883396 \\
\hline $\mathrm{H}$ & -3.054681 & 2.781449 & 1.943705 \\
\hline $\mathrm{H}$ & -3.986018 & 4.662226 & 3.791552 \\
\hline $\mathrm{H}$ & -5.937247 & -4.914193 & -3.491418 \\
\hline $\mathrm{H}$ & -3.715208 & -4.273814 & -1.895371 \\
\hline $\mathrm{H}$ & -3.688256 & 0.221294 & -2.843862 \\
\hline $\mathrm{H}$ & -2.463358 & 2.744348 & -2.733774 \\
\hline $\mathrm{H}$ & 1.271325 & 3.484433 & 2.449552 \\
\hline $\mathrm{H}$ & 3.377149 & 1.631322 & 2.524967 \\
\hline $\mathrm{H}$ & 4.331853 & 2.470920 & -1.932381 \\
\hline $\mathrm{H}$ & 6.829101 & 2.969899 & -3.085104 \\
\hline $\mathrm{H}$ & 4.773193 & -2.468744 & 2.094678 \\
\hline $\mathrm{H}$ & 7.113371 & -2.229551 & 3.628008 \\
\hline $\mathrm{H}$ & -7.519884 & -2.909445 & -3.175085 \\
\hline $\mathrm{H}$ & -2.416217 & 6.680944 & 3.471567 \\
\hline $\mathrm{H}$ & 8.013832 & 0.102890 & 3.015770 \\
\hline $\mathrm{Ni}$ & 0.984801 & -5.347043 & 0.277545 \\
\hline $\mathrm{C}$ & 1.864129 & -2.332541 & 1.568021 \\
\hline $\mathrm{N}$ & -2.375276 & -2.975775 & 0.520348 \\
\hline $\mathrm{N}$ & -0.641035 & -4.384189 & 0.606858 \\
\hline $\mathrm{C}$ & -2.453111 & -3.669794 & 1.713331 \\
\hline $\mathrm{C}$ & -1.390232 & -4.548828 & 1.762188 \\
\hline $\mathrm{C}$ & 2.335155 & -2.685549 & 0.193237 \\
\hline $\mathrm{C}$ & -1.266615 & -3.422062 & -0.123397 \\
\hline $\mathrm{N}$ & 2.012315 & -3.827794 & -0.461345 \\
\hline $\mathrm{N}$ & 3.111537 & -1.879342 & -0.576626 \\
\hline $\mathrm{C}$ & -0.809600 & -2.887855 & -1.442565 \\
\hline $\mathrm{C}$ & 2.600734 & -3.735796 & -1.709608 \\
\hline $\mathrm{C}$ & 3.276793 & -2.530015 & -1.783578 \\
\hline $\mathrm{H}$ & -0.326489 & -3.672982 & -2.051865 \\
\hline $\mathrm{H}$ & -0.065676 & -2.072486 & -1.318628 \\
\hline $\mathrm{H}$ & -1.663248 & -2.465207 & -2.004953 \\
\hline $\mathrm{H}$ & 0.764480 & -2.186501 & 1.588710 \\
\hline $\mathrm{H}$ & 2.336956 & -1.393085 & 1.910772 \\
\hline $\mathrm{H}$ & 2.085453 & -3.136617 & 2.299350 \\
\hline $\mathrm{H}$ & -3.263128 & -3.493347 & 2.428317 \\
\hline $\mathrm{H}$ & -1.111436 & -5.280873 & 2.525665 \\
\hline $\mathrm{H}$ & 2.487536 & -4.520075 & -2.466379 \\
\hline $\mathrm{H}$ & 3.859570 & -2.083690 & -2.597301 \\
\hline $\mathrm{H}$ & 1.096201 & 7.802175 & -2.440620 \\
\hline $\mathrm{H}$ & 1.664167 & 5.188450 & -1.614006 \\
\hline $\mathrm{C}$ & 2.495439 & -6.373307 & 1.051484 \\
\hline $\mathrm{H}$ & 3.255935 & -5.623299 & 1.330694 \\
\hline $\mathrm{C}$ & 2.327859 & -6.722576 & -0.295901 \\
\hline $\mathrm{H}$ & 1.811193 & -7.654057 & -0.578028 \\
\hline $\mathrm{H}$ & 2.970418 & -6.269443 & -1.067177 \\
\hline $\mathrm{H}$ & 0.309787 & -6.489746 & 0.829256 \\
\hline $\mathrm{H}$ & 2.158015 & -7.033750 & 1.865305 \\
\hline
\end{tabular}

\section{4}

3. Ni-betaH-Et SCF Done: -4915.22313778 A.U.

$\begin{array}{rrrr}\mathrm{C} & -0.189847 & 6.587167 & 1.453184 \\ \mathrm{C} & -6.200006 & -2.783463 & 1.984059 \\ \mathrm{C} & 6.643757 & 1.539898 & 1.213100 \\ \mathrm{C} & -1.409723 & 0.546673 & 1.176422 \\ \mathrm{~N} & -1.465838 & 4.397011 & 1.451145 \\ \mathrm{~N} & -6.984275 & -0.424870 & 2.296835 \\ \mathrm{~N} & 7.086628 & -0.404986 & 2.758687 \\ \mathrm{~N} & -2.161687 & 5.915996 & 2.877877 \\ \mathrm{~N} & -4.976023 & -0.690570 & 1.275209 \\ \mathrm{~N} & 5.277793 & -0.571325 & 1.522618 \\ \mathrm{~N} & 2.757300 & 1.175483 & 0.489792 \\ \mathrm{~N} & 1.124516 & 2.699543 & 0.399945 \\ \mathrm{C} & -2.569394 & 3.896720 & 2.117532 \\ \mathrm{C} & -6.462396 & 0.813072 & 1.999750 \\ \mathrm{C} & 6.534457 & -1.639548 & 3.053781 \\ \mathrm{C} & -3.018888 & 4.838019 & 3.018886 \\ \mathrm{C} & -5.231163 & 0.668052 & 1.367553 \\ \mathrm{C} & 5.403467 & -1.726823 & 2.269301 \\ \mathrm{C} & 2.713477 & 1.823281 & 1.709483 \\ \mathrm{C} & 1.701193 & 2.767134 & 1.653469\end{array}$




\begin{tabular}{|c|c|c|c|}
\hline $\mathrm{C}$ & -1.231550 & 5.631205 & 1.919197 \\
\hline $\mathrm{C}$ & -6.067432 & -1.296497 & 1.850476 \\
\hline $\mathrm{C}$ & 6.314403 & 0.223756 & 1.824447 \\
\hline $\mathrm{C}$ & -1.971211 & 0.906853 & -0.162113 \\
\hline $\mathrm{C}$ & 1.784751 & 1.728054 & -0.274362 \\
\hline $\mathrm{N}$ & -2.780458 & 0.086569 & -0.874129 \\
\hline $\mathrm{N}$ & -1.743038 & 2.066527 & -0.825277 \\
\hline $\mathrm{N}$ & 5.296795 & 0.385185 & -1.481266 \\
\hline $\mathrm{N}$ & -4.934084 & -2.353875 & -1.441155 \\
\hline $\mathrm{N}$ & -0.350303 & 5.115933 & -1.422612 \\
\hline C & 1.454481 & 1.281772 & -1.662008 \\
\hline C & -3.077707 & 0.751307 & -2.047786 \\
\hline $\mathrm{C}$ & -2.432541 & 1.976838 & -2.020114 \\
\hline $\mathrm{C}$ & 5.326481 & 1.669968 & -1.998035 \\
\hline $\mathrm{C}$ & 6.555332 & -0.122302 & -1.714103 \\
\hline $\mathrm{C}$ & -6.133266 & -1.899223 & -1.832073 \\
\hline $\mathrm{C}$ & -4.734181 & -3.584427 & -2.037534 \\
\hline $\mathrm{C}$ & -1.288311 & 6.097538 & -1.644961 \\
\hline $\mathrm{C}$ & 0.863226 & 5.691876 & -1.759940 \\
\hline $\mathrm{C}$ & 6.597930 & 1.871993 & -2.524074 \\
\hline $\mathrm{N}$ & 7.365248 & 0.743732 & -2.339047 \\
\hline $\mathrm{C}$ & 6.983576 & -1.492533 & -1.279606 \\
\hline $\mathrm{N}$ & -6.691363 & -2.818956 & -2.672899 \\
\hline $\mathrm{C}$ & -6.799154 & -0.638206 & -1.406403 \\
\hline $\mathrm{C}$ & -5.829151 & -3.891975 & -2.817596 \\
\hline $\mathrm{N}$ & -0.755569 & 7.241034 & -2.098109 \\
\hline $\mathrm{C}$ & -2.751200 & 5.909320 & -1.373232 \\
\hline $\mathrm{C}$ & 0.596540 & 6.992128 & -2.175935 \\
\hline $\mathrm{Zn}$ & 4.031468 & -0.240859 & -0.118519 \\
\hline $\mathrm{Zn}$ & -3.711094 & -1.467286 & -0.017238 \\
\hline $\mathrm{Zn}$ & -0.564754 & 3.578073 & -0.241761 \\
\hline $\mathrm{H}$ & 2.359020 & 0.910961 & -2.182329 \\
\hline $\mathrm{H}$ & 1.026703 & 2.113734 & -2.253474 \\
\hline $\mathrm{H}$ & 0.706373 & 0.460625 & -1.655198 \\
\hline $\mathrm{H}$ & -2.217416 & 0.281181 & 1.889867 \\
\hline $\mathrm{H}$ & -0.818930 & 1.379231 & 1.597541 \\
\hline $\mathrm{H}$ & -0.739927 & -0.334562 & 1.102166 \\
\hline $\mathrm{H}$ & -7.206576 & -0.729129 & -0.375573 \\
\hline $\mathrm{H}$ & -7.623791 & -0.372779 & -2.094960 \\
\hline $\mathrm{H}$ & -6.073090 & 0.196037 & -1.377326 \\
\hline $\mathrm{H}$ & -7.255424 & -3.035614 & 2.197790 \\
\hline $\mathrm{H}$ & -5.589191 & -3.185265 & 2.822324 \\
\hline $\mathrm{H}$ & -5.881857 & -3.318377 & 1.064842 \\
\hline $\mathrm{H}$ & 7.847344 & -1.813603 & -1.891211 \\
\hline $\mathrm{H}$ & 6.169988 & -2.237574 & -1.389499 \\
\hline $\mathrm{H}$ & 7.303720 & -1.523200 & -0.213867 \\
\hline $\mathrm{H}$ & -0.514957 & 7.109905 & 0.526410 \\
\hline $\mathrm{H}$ & 0.742523 & 6.053194 & 1.191345 \\
\hline $\mathrm{H}$ & 0.033675 & 7.343109 & 2.230296 \\
\hline $\mathrm{H}$ & -3.093949 & 4.886895 & -1.631120 \\
\hline $\mathrm{H}$ & -3.329529 & 6.639872 & -1.969041 \\
\hline $\mathrm{H}$ & -3.015116 & 6.071588 & -0.303690 \\
\hline $\mathrm{H}$ & 7.291458 & 2.138712 & 1.881888 \\
\hline $\mathrm{H}$ & 5.720578 & 2.110331 & 1.000462 \\
\hline $\mathrm{H}$ & 7.163078 & 1.402266 & 0.239112 \\
\hline $\mathrm{H}$ & -6.996226 & 1.740557 & 2.249155 \\
\hline $\mathrm{H}$ & -4.547319 & 1.411622 & 0.938552 \\
\hline $\mathrm{H}$ & -2.972560 & 2.901170 & 1.905630 \\
\hline $\mathrm{H}$ & -3.848696 & 4.831405 & 3.731147 \\
\hline $\mathrm{H}$ & -6.063421 & -4.753938 & -3.448556 \\
\hline $\mathrm{H}$ & -3.821791 & -4.163367 & -1.858855 \\
\hline $\mathrm{H}$ & -3.717536 & 0.304680 & -2.817276 \\
\hline $\mathrm{H}$ & -2.400149 & 2.783046 & -2.761429 \\
\hline $\mathrm{H}$ & 1.348447 & 3.474588 & 2.412152 \\
\hline $\mathrm{H}$ & 3.403245 & 1.566623 & 2.521249 \\
\hline $\mathrm{H}$ & 4.451261 & 2.329923 & -1.949644 \\
\hline $\mathrm{H}$ & 6.991359 & 2.761656 & -3.034416 \\
\hline $\mathrm{H}$ & 4.678796 & -2.543360 & 2.187503 \\
\hline $\mathrm{H}$ & 6.981267 & -2.325728 & 3.778662 \\
\hline $\mathrm{H}$ & -7.607619 & -2.722969 & -3.111899 \\
\hline $\mathrm{H}$ & -2.217063 & 6.796761 & 3.390048 \\
\hline
\end{tabular}

\begin{tabular}{|c|c|c|c|}
\hline $\mathrm{H}$ & 7.946315 & -0.022537 & 3.153630 \\
\hline $\mathrm{Ni}$ & 0.912614 & -5.300531 & 0.131821 \\
\hline $\mathrm{C}$ & 1.791940 & -2.368170 & 1.544929 \\
\hline $\mathrm{N}$ & -2.425481 & -2.882877 & 0.544787 \\
\hline $\mathrm{N}$ & -0.687766 & -4.295924 & 0.586050 \\
\hline $\mathrm{C}$ & -2.460737 & -3.559993 & 1.747931 \\
\hline $\mathrm{C}$ & -1.390091 & -4.435172 & 1.771966 \\
\hline $\mathrm{C}$ & 2.303616 & -2.746013 & 0.193193 \\
\hline $\mathrm{C}$ & -1.339547 & -3.346938 & -0.130643 \\
\hline $\mathrm{N}$ & 1.997428 & -3.893152 & -0.464895 \\
\hline $\mathrm{N}$ & 3.120263 & -1.964690 & -0.558682 \\
\hline $\mathrm{C}$ & -0.899017 & -2.825935 & -1.460729 \\
\hline $\mathrm{C}$ & 2.643911 & -3.834160 & -1.687569 \\
\hline $\mathrm{C}$ & 3.332167 & -2.636013 & -1.747142 \\
\hline $\mathrm{H}$ & -0.379881 & -3.611450 & -2.040006 \\
\hline $\mathrm{H}$ & -0.185130 & -1.981381 & -1.350850 \\
\hline $\mathrm{H}$ & -1.759601 & -2.446288 & -2.043345 \\
\hline $\mathrm{H}$ & 0.700988 & -2.169282 & 1.521562 \\
\hline $\mathrm{H}$ & 2.296516 & -1.452339 & 1.906089 \\
\hline $\mathrm{H}$ & 1.945087 & -3.182737 & 2.281213 \\
\hline $\mathrm{H}$ & -3.244207 & -3.373538 & 2.489898 \\
\hline $\mathrm{H}$ & -1.079218 & -5.143152 & 2.548260 \\
\hline $\mathrm{H}$ & 2.568214 & -4.641454 & -2.422298 \\
\hline $\mathrm{H}$ & 3.957698 & -2.209591 & -2.539286 \\
\hline $\mathrm{H}$ & 1.303522 & 7.750695 & -2.538639 \\
\hline $\mathrm{H}$ & 1.803987 & 5.131533 & -1.685962 \\
\hline $\mathrm{C}$ & 2.194003 & -6.676408 & -0.112640 \\
\hline $\mathrm{H}$ & 2.466195 & -6.855110 & -1.168752 \\
\hline $\mathrm{H}$ & 3.071767 & -6.577671 & 0.550746 \\
\hline $\mathrm{C}$ & 1.001342 & -7.374170 & 0.417310 \\
\hline $\mathrm{H}$ & 0.515873 & -8.094659 & -0.270727 \\
\hline $\mathrm{H}$ & 0.071130 & -6.622060 & 0.594898 \\
\hline $\mathrm{H}$ & 1.100426 & -7.810602 & 1.431000 \\
\hline \multicolumn{4}{|c|}{$\begin{array}{l}------------------------------------------- \\
130\end{array}$} \\
\hline . $\mathrm{N}$ & etaH-Et-Et & SCF Done: -49 & .66841214 \\
\hline $\mathrm{C}$ & -0.079433 & 6.746414 & 1.494767 \\
\hline $\mathrm{C}$ & -6.258501 & -2.525915 & 1.960832 \\
\hline $\mathrm{C}$ & 6.654745 & 1.625539 & 1.183684 \\
\hline $\mathrm{C}$ & -1.396316 & 0.724096 & 1.170649 \\
\hline $\mathrm{N}$ & -1.390907 & 4.577490 & 1.474084 \\
\hline $\mathrm{N}$ & -7.022251 & -0.161169 & 2.277219 \\
\hline $\mathrm{N}$ & 7.164783 & -0.376702 & 2.633273 \\
\hline $\mathrm{N}$ & -2.072049 & 6.101262 & 2.902743 \\
\hline $\mathrm{N}$ & -5.009116 & -0.441305 & 1.269646 \\
\hline $\mathrm{N}$ & 5.321988 & -0.512136 & 1.444529 \\
\hline $\mathrm{N}$ & 2.777273 & 1.283561 & 0.490021 \\
\hline $\mathrm{N}$ & 1.173829 & 2.839393 & 0.414948 \\
\hline $\mathrm{C}$ & -2.507072 & 4.092224 & 2.130464 \\
\hline $\mathrm{C}$ & -6.486975 & 1.073159 & 1.988735 \\
\hline $\mathrm{C}$ & 6.636085 & -1.630115 & 2.889540 \\
\hline $\mathrm{C}$ & -2.947610 & 5.036743 & 3.032868 \\
\hline $\mathrm{C}$ & -5.252443 & 0.919293 & 1.365256 \\
\hline $\mathrm{C}$ & 5.483501 & -1.697300 & 2.135010 \\
\hline $\mathrm{C}$ & 2.749827 & 1.924726 & 1.713995 \\
\hline $\mathrm{C}$ & 1.755347 & 2.887942 & 1.667010 \\
\hline $\mathrm{C}$ & -1.139968 & 5.805663 & 1.949213 \\
\hline $\mathrm{C}$ & -6.110295 & -1.039685 & 1.834484 \\
\hline $\mathrm{C}$ & 6.357988 & 0.281834 & 1.749967 \\
\hline $\mathrm{C}$ & -1.959208 & 1.111804 & -0.159826 \\
\hline $\mathrm{C}$ & 1.812928 & 1.859674 & -0.267675 \\
\hline $\mathrm{N}$ & -2.793307 & 0.318250 & -0.873710 \\
\hline $\mathrm{N}$ & -1.706749 & 2.271073 & -0.814576 \\
\hline $\mathrm{N}$ & 5.277276 & 0.511863 & -1.520965 \\
\hline $\mathrm{N}$ & -4.965748 & -2.109031 & -1.445617 \\
\hline $\mathrm{N}$ & -0.256162 & 5.295665 & -1.391177 \\
\hline $\mathrm{C}$ & 1.470374 & 1.429544 & -1.657485 \\
\hline $\mathrm{C}$ & -3.081097 & 1.000143 & -2.039964 \\
\hline $\mathrm{C}$ & -2.405309 & 2.208800 & -2.005925 \\
\hline $\mathrm{C}$ & 5.298819 & 1.807238 & -2.011154 \\
\hline $\mathrm{C}$ & 6.532108 & 0.010272 & -1.784380 \\
\hline
\end{tabular}




\begin{tabular}{|c|c|c|c|}
\hline $\mathrm{C}$ & -6.162829 & -1.650573 & -1.838563 \\
\hline $\mathrm{C}$ & -4.773775 & -3.345148 & -2.032886 \\
\hline $\mathrm{C}$ & -1.176553 & 6.294341 & -1.611362 \\
\hline $\mathrm{C}$ & 0.967810 & 5.851437 & -1.724733 \\
\hline $\mathrm{C}$ & 6.561934 & 2.020921 & -2.552525 \\
\hline $\mathrm{N}$ & 7.332075 & 0.889397 & -2.403627 \\
\hline $\mathrm{C}$ & 6.968491 & -1.368628 & -1.385915 \\
\hline $\mathrm{N}$ & -6.727149 & -2.573401 & -2.671845 \\
\hline $\mathrm{C}$ & -6.821498 & -0.383454 & -1.419946 \\
\hline $\mathrm{C}$ & -5.871338 & -3.652433 & -2.809373 \\
\hline $\mathrm{N}$ & -0.623065 & 7.429885 & -2.059510 \\
\hline $\mathrm{C}$ & -2.643069 & 6.131430 & -1.342523 \\
\hline $\mathrm{C}$ & 0.724569 & 7.157725 & -2.136127 \\
\hline $\mathrm{Zn}$ & 4.031197 & -0.139198 & -0.150805 \\
\hline $\mathrm{Zn}$ & -3.745539 & -1.222365 & -0.019341 \\
\hline $\mathrm{Zn}$ & -0.498048 & 3.754378 & -0.220732 \\
\hline $\mathrm{H}$ & 2.365202 & 1.039916 & -2.180707 \\
\hline $\mathrm{H}$ & 1.063684 & 2.275768 & -2.243671 \\
\hline $\mathrm{H}$ & 0.701727 & 0.627690 & -1.655214 \\
\hline $\mathrm{H}$ & -2.204507 & 0.457372 & 1.883049 \\
\hline $\mathrm{H}$ & -0.795885 & 1.544072 & 1.602881 \\
\hline $\mathrm{H}$ & -0.738183 & -0.164502 & 1.080719 \\
\hline $\mathrm{H}$ & -7.236169 & -0.469336 & -0.391471 \\
\hline $\mathrm{H}$ & -7.639569 & -0.112853 & -2.114292 \\
\hline $\mathrm{H}$ & -6.089124 & 0.445090 & -1.387382 \\
\hline $\mathrm{H}$ & -7.314339 & -2.765957 & 2.185827 \\
\hline $\mathrm{H}$ & -5.641728 & -2.940623 & 2.788121 \\
\hline $\mathrm{H}$ & -5.958262 & -3.059938 & 1.035013 \\
\hline $\mathrm{H}$ & 7.774442 & -1.707493 & -2.063784 \\
\hline $\mathrm{H}$ & 6.134695 & -2.097560 & -1.429963 \\
\hline $\mathrm{H}$ & 7.375097 & -1.407412 & -0.350136 \\
\hline $\mathrm{H}$ & -0.390740 & 7.281375 & 0.570301 \\
\hline $\mathrm{H}$ & 0.844498 & 6.197765 & 1.233435 \\
\hline $\mathrm{H}$ & 0.153810 & 7.492804 & 2.278231 \\
\hline $\mathrm{H}$ & -3.002030 & 5.113720 & -1.596770 \\
\hline $\mathrm{H}$ & -3.207906 & 6.868769 & -1.942960 \\
\hline $\mathrm{H}$ & -2.907112 & 6.303340 & -0.274513 \\
\hline $\mathrm{H}$ & 7.309677 & 2.207781 & 1.860035 \\
\hline $\mathrm{H}$ & 5.718949 & 2.190044 & 1.014688 \\
\hline $\mathrm{H}$ & 7.152854 & 1.532684 & 0.193555 \\
\hline $\mathrm{H}$ & -7.014044 & 2.004423 & 2.238313 \\
\hline $\mathrm{H}$ & -4.557528 & 1.658044 & 0.945724 \\
\hline $\mathrm{H}$ & -2.924690 & 3.104287 & 1.910935 \\
\hline $\mathrm{H}$ & -3.782451 & 5.040539 & 3.739248 \\
\hline $\mathrm{H}$ & -6.111482 & -4.517812 & -3.433422 \\
\hline $\mathrm{H}$ & -3.864494 & -3.928018 & -1.850784 \\
\hline $\mathrm{H}$ & -3.737069 & 0.576882 & -2.809100 \\
\hline $\mathrm{H}$ & -2.357589 & 3.020407 & -2.740474 \\
\hline $\mathrm{H}$ & 1.418400 & 3.597193 & 2.431171 \\
\hline $\mathrm{H}$ & 3.437315 & 1.650422 & 2.521914 \\
\hline $\mathrm{H}$ & 4.424665 & 2.465911 & -1.935654 \\
\hline $\mathrm{H}$ & 6.947004 & 2.921310 & -3.050339 \\
\hline $\mathrm{H}$ & 4.769469 & -2.520655 & 2.032634 \\
\hline $\mathrm{H}$ & 7.112496 & -2.341826 & 3.569548 \\
\hline $\mathrm{H}$ & -7.643552 & -2.475762 & -3.110233 \\
\hline $\mathrm{H}$ & -2.116789 & 6.980514 & 3.418558 \\
\hline $\mathrm{H}$ & 8.031702 & -0.001220 & 3.019004 \\
\hline $\mathrm{Ni}$ & 0.764259 & -5.248846 & 0.167448 \\
\hline $\mathrm{C}$ & 1.752822 & -2.157380 & 1.538672 \\
\hline $\mathrm{N}$ & -2.474149 & -2.643216 & 0.559095 \\
\hline $\mathrm{N}$ & -0.797831 & -4.126028 & 0.597671 \\
\hline $\mathrm{C}$ & -2.512939 & -3.293930 & 1.776698 \\
\hline $\mathrm{C}$ & -1.480567 & -4.214444 & 1.797808 \\
\hline $\mathrm{C}$ & 2.231496 & -2.583765 & 0.187913 \\
\hline $\mathrm{C}$ & -1.420965 & -3.164484 & -0.126688 \\
\hline $\mathrm{N}$ & 1.894549 & -3.738414 & -0.435989 \\
\hline $\mathrm{N}$ & 3.087053 & -1.848788 & -0.572180 \\
\hline $\mathrm{C}$ & -0.982582 & -2.675448 & -1.469630 \\
\hline $\mathrm{C}$ & 2.562757 & -3.733342 & -1.648145 \\
\hline $\mathrm{C}$ & 3.295365 & -2.562467 & -1.735340 \\
\hline $\mathrm{H}$ & -0.621372 & -3.503109 & -2.108502 \\
\hline
\end{tabular}

$\begin{array}{rrrr}\mathrm{H} & -0.143160 & -1.953684 & -1.380638 \\ \mathrm{H} & -1.809906 & -2.154649 & -1.986463 \\ \mathrm{H} & 0.725080 & -2.520996 & 1.721050 \\ \mathrm{H} & 1.768073 & -1.053085 & 1.619041 \\ \mathrm{H} & 2.389865 & -2.557983 & 2.357322 \\ \mathrm{H} & -3.269544 & -3.054244 & 2.531227 \\ \mathrm{H} & -1.179802 & -4.923127 & 2.576404 \\ \mathrm{H} & 2.469495 & -4.557963 & -2.363596 \\ \mathrm{H} & 3.937321 & -2.176362 & -2.535145 \\ \mathrm{H} & 1.445282 & 7.905122 & -2.494963 \\ \mathrm{H} & 1.898464 & 5.274291 & -1.651848 \\ \mathrm{C} & 1.874325 & -5.933633 & 1.656166 \\ \mathrm{H} & 2.307543 & -5.050321 & 2.155197 \\ \mathrm{C} & 2.400200 & -6.389747 & 0.425442 \\ \mathrm{H} & 3.268183 & -5.887865 & -0.029659 \\ \mathrm{H} & 2.234830 & -7.433316 & 0.109517 \\ \mathrm{H} & 1.303758 & -6.609267 & 2.314809 \\ \mathrm{C} & -0.399540 & -6.778281 & 0.151947 \\ \mathrm{H} & -1.326738 & -6.627559 & 0.731333 \\ \mathrm{H} & 0.099606 & -7.723440 & 0.435313 \\ \mathrm{C} & -0.520819 & -6.538411 & -1.338678 \\ \mathrm{H} & -1.525047 & -6.183624 & -1.643909 \\ \mathrm{H} & -0.221696 & -7.408604 & -1.957082 \\ \mathrm{H} & 0.184657 & -5.711935 & -1.685548 \\ -----------------------------------\end{array}$

\section{0}

4-5 TS-ins-Et SCF Done: -4993.64497050 A.U.

\begin{tabular}{|c|c|c|c|}
\hline & & & \\
\hline C & 1.085388 & 6.743785 & 1.279598 \\
\hline $\mathrm{C}$ & -6.503230 & -1.873791 & 1.844865 \\
\hline C & 6.840374 & 0.527329 & 1.470993 \\
\hline $\mathrm{C}$ & -1.303668 & 1.017682 & 1.214561 \\
\hline $\mathrm{N}$ & -0.608887 & 4.862654 & 1.388514 \\
\hline N & -6.944266 & 0.483052 & 2.569712 \\
\hline$N$ & 6.834193 & -1.538810 & 2.921470 \\
\hline $\mathrm{N}$ & -0.959809 & 6.553472 & 2.746657 \\
\hline $\mathrm{N}$ & -5.007790 & 0.125588 & 1.444072 \\
\hline $\mathrm{N}$ & 5.107057 & -1.315861 & 1.582186 \\
\hline $\mathrm{N}$ & 2.958579 & 0.890134 & 0.532845 \\
\hline $\mathrm{N}$ & 1.585045 & 2.650548 & 0.424393 \\
\hline C & -1.777882 & 4.625314 & 2.087446 \\
\hline C & -6.276769 & 1.678588 & 2.429596 \\
\hline C & 6.054790 & -2.667194 & 3.111434 \\
\hline C & -2.012955 & 5.677551 & 2.946915 \\
\hline C & -5.087989 & 1.476940 & 1.735477 \\
\hline C & 4.978831 & -2.510812 & 2.263072 \\
\hline C & 2.990194 & 1.530062 & 1.757012 \\
\hline C & 2.138304 & 2.620396 & 1.689633 \\
\hline $\mathrm{C}$ & -0.122738 & 6.043851 & 1.795562 \\
\hline C & -6.155970 & -0.420408 & 1.968561 \\
\hline C & 6.246192 & -0.736155 & 1.985989 \\
\hline C & -1.822653 & 1.477031 & -0.110735 \\
\hline C & 2.100099 & 1.591922 & -0.245272 \\
\hline $\mathrm{N}$ & -2.795500 & 0.830762 & -0.797665 \\
\hline $\mathrm{N}$ & -1.371333 & 2.553560 & -0.798831 \\
\hline $\mathrm{N}$ & 5.434248 & -0.204621 & -1.349563 \\
\hline $\mathrm{N}$ & -5.273497 & -1.248035 & -1.400364 \\
\hline $\mathrm{N}$ & 0.603453 & 5.204580 & -1.527635 \\
\hline $\mathrm{C}$ & 1.732787 & 1.216447 & -1.644635 \\
\hline $\mathrm{C}$ & -2.967235 & 1.523546 & -1.980882 \\
\hline C & -2.082577 & 2.589096 & -1.983478 \\
\hline C & 5.695258 & 1.084265 & -1.783995 \\
\hline $\mathrm{C}$ & 6.610137 & -0.893005 & -1.546824 \\
\hline $\mathrm{C}$ & -6.418124 & -0.603316 & -1.668417 \\
\hline $\mathrm{C}$ & -5.319584 & -2.471848 & -2.039488 \\
\hline $\mathrm{C}$ & -0.112857 & 6.348896 & -1.794000 \\
\hline $\mathrm{C}$ & 1.902885 & 5.494729 & -1.908712 \\
\hline $\mathrm{C}$ & 7.012630 & 1.108284 & -2.229539 \\
\hline $\mathrm{N}$ & 7.582210 & -0.135598 & -2.074198 \\
\hline $\mathrm{C}$ & 6.792200 & -2.333413 & -1.170076 \\
\hline $\mathrm{N}$ & -7.183002 & -1.395894 & -2.475126 \\
\hline $\mathrm{C}$ & -6.844254 & 0.723058 & -1.1450 \\
\hline
\end{tabular}




\begin{tabular}{|c|c|c|c|}
\hline $\mathrm{C}$ & -6.512833 & -2.581646 & -2.722238 \\
\hline $\mathrm{N}$ & 0.637192 & 7.329640 & -2.315523 \\
\hline $\mathrm{C}$ & -1.574307 & 6.489074 & -1.488478 \\
\hline $\mathrm{C}$ & 1.905076 & 6.798515 & -2.393672 \\
\hline $\mathrm{Zn}$ & 4.016737 & -0.692125 & -0.084755 \\
\hline $\mathrm{Zn}$ & -3.887519 & -0.634831 & 0.018039 \\
\hline $\mathrm{Zn}$ & 0.095577 & 3.806521 & -0.263383 \\
\hline $\mathrm{H}$ & 2.569061 & 0.688533 & -2.142850 \\
\hline $\mathrm{H}$ & 1.482108 & 2.115531 & -2.240290 \\
\hline $\mathrm{H}$ & 0.848136 & 0.545188 & -1.664847 \\
\hline $\mathrm{H}$ & -0.691978 & 0.097495 & 1.106580 \\
\hline $\mathrm{H}$ & -2.135128 & 0.777522 & 1.907829 \\
\hline $\mathrm{H}$ & -0.660085 & 1.785510 & 1.679612 \\
\hline $\mathrm{H}$ & -7.216963 & 0.637382 & -0.100616 \\
\hline $\mathrm{H}$ & -7.641714 & 1.161498 & -1.774848 \\
\hline $\mathrm{H}$ & -5.986467 & 1.420600 & -1.113541 \\
\hline $\mathrm{H}$ & -7.348822 & -2.099012 & 2.520461 \\
\hline $\mathrm{H}$ & -5.651638 & -2.534177 & 2.107959 \\
\hline $\mathrm{H}$ & -6.810215 & -2.151212 & 0.811987 \\
\hline $\mathrm{H}$ & 7.560239 & -2.790746 & -1.822013 \\
\hline $\mathrm{H}$ & 5.850755 & -2.909718 & -1.267660 \\
\hline $\mathrm{H}$ & 7.139441 & -2.459012 & -0.119751 \\
\hline $\mathrm{H}$ & 0.862131 & 7.281928 & 0.331753 \\
\hline $\mathrm{H}$ & 1.882967 & 6.016884 & 1.037700 \\
\hline $\mathrm{H}$ & 1.471933 & 7.470277 & 2.019931 \\
\hline $\mathrm{H}$ & -2.124645 & 5.539748 & -1.645837 \\
\hline $\mathrm{H}$ & -2.012694 & 7.268547 & -2.139326 \\
\hline $\mathrm{H}$ & -1.762369 & 6.795109 & -0.434681 \\
\hline $\mathrm{H}$ & 7.536313 & 0.971149 & 2.208576 \\
\hline $\mathrm{H}$ & 6.046877 & 1.261148 & 1.236672 \\
\hline $\mathrm{H}$ & 7.390961 & 0.345279 & 0.521296 \\
\hline $\mathrm{H}$ & -6.678854 & 2.615992 & 2.838038 \\
\hline $\mathrm{H}$ & -4.313322 & 2.181332 & 1.405717 \\
\hline $\mathrm{H}$ & -2.372868 & 3.719825 & 1.928225 \\
\hline $\mathrm{H}$ & -2.813095 & 5.870975 & 3.666861 \\
\hline $\mathrm{H}$ & -6.931427 & -3.374210 & -3.348772 \\
\hline $\mathrm{H}$ & -4.496726 & -3.189196 & -1.958410 \\
\hline $\mathrm{H}$ & -3.699819 & 1.208376 & -2.732446 \\
\hline $\mathrm{H}$ & -1.896261 & 3.360825 & -2.738617 \\
\hline $\mathrm{H}$ & 1.883918 & 3.370782 & 2.446543 \\
\hline $\mathrm{H}$ & 3.614838 & 1.165552 & 2.580252 \\
\hline $\mathrm{H}$ & 4.930965 & 1.870689 & -1.745448 \\
\hline $\mathrm{H}$ & 7.570296 & 1.949440 & -2.663458 \\
\hline $\mathrm{H}$ & 4.127964 & -3.177800 & 2.090245 \\
\hline $\mathrm{H}$ & 6.326327 & -3.457445 & 3.816900 \\
\hline $\mathrm{H}$ & -8.108825 & -1.146472 & -2.824568 \\
\hline $\mathrm{H}$ & -0.827548 & 7.449151 & 3.217275 \\
\hline $\mathrm{H}$ & 7.721321 & -1.337991 & 3.384011 \\
\hline $\mathrm{Ni}$ & 0.060965 & -5.203473 & -0.181362 \\
\hline $\mathrm{C}$ & 1.357644 & -2.376396 & 1. 388424 \\
\hline $\mathrm{N}$ & -2.748288 & -2.200972 & 0.491991 \\
\hline $\mathrm{N}$ & -1.273451 & -3.884811 & 0.416087 \\
\hline $\mathrm{C}$ & -2.709717 & -2.785550 & 1.742490 \\
\hline $\mathrm{C}$ & -1.798933 & -3.828105 & 1.693664 \\
\hline $\mathrm{C}$ & 1.873639 & -2.854218 & 0.070301 \\
\hline $\mathrm{C}$ & -1.861524 & -2.885475 & -0.280523 \\
\hline $\mathrm{N}$ & 1.411469 & -3.931859 & -0.612639 \\
\hline $\mathrm{N}$ & 2.856180 & -2.225737 & -0.625960 \\
\hline $\mathrm{C}$ & -1.562642 & -2.560112 & -1.708899 \\
\hline $\mathrm{C}$ & 2.132468 & -3.986278 & -1.794892 \\
\hline $\mathrm{C}$ & 3.019602 & -2.925431 & -1.805504 \\
\hline $\mathrm{H}$ & -0.468413 & -2.504724 & -1.875990 \\
\hline $\mathrm{H}$ & -2.011037 & -1.586945 & -1.985339 \\
\hline $\mathrm{H}$ & -1.951014 & -3.334850 & -2.404842 \\
\hline $\mathrm{H}$ & 0.362425 & -1.897202 & 1.282525 \\
\hline $\mathrm{H}$ & 2.044358 & -1.625976 & 1.823041 \\
\hline $\mathrm{H}$ & 1.227886 & -3.211688 & 2.103852 \\
\hline $\mathrm{H}$ & -3.318334 & -2.406747 & 2.571142 \\
\hline $\mathrm{H}$ & -1.481568 & -4.519681 & 2.482307 \\
\hline $\mathrm{H}$ & 1.965868 & -4.775769 & -2.534242 \\
\hline $\mathrm{H}$ & 3.754334 & -2.614958 & -2.556763 \\
\hline
\end{tabular}

$\begin{array}{rrrr}\mathrm{H} & 2.747089 & 7.371398 & -2.805411 \\ \mathrm{H} & 2.707376 & 4.754336 & -1.812927 \\ \mathrm{C} & 0.114391 & -7.048558 & 0.593557 \\ \mathrm{H} & 0.072267 & -6.698655 & 1.646744 \\ \mathrm{C} & 1.295736 & -6.687747 & -0.174715 \\ \mathrm{H} & 1.475890 & -7.232672 & -1.119896 \\ \mathrm{H} & 2.213503 & -6.362564 & 0.341132 \\ \mathrm{C} & -1.413719 & -6.591154 & -0.588583 \\ \mathrm{H} & -1.511787 & -5.708849 & -1.276511 \\ \mathrm{H} & -1.163687 & -7.444241 & -1.245651 \\ \mathrm{C} & -2.682752 & -6.816908 & 0.208168 \\ \mathrm{H} & -2.943554 & -5.934300 & 0.823096 \\ \mathrm{H} & -3.536132 & -7.014588 & -0.475149 \\ \mathrm{H} & -2.598337 & -7.693635 & 0.884163 \\ \mathrm{H} & -0.301993 & -8.068222 & 0.534261 \\ ---------------------------------------\end{array}$

130

5. Ni-betaH-Bu SCF Done: -4993.68810487 A.U.

\begin{tabular}{|c|c|c|c|}
\hline $\mathrm{C}$ & 1.657801 & -6.492876 & 1.738903 \\
\hline C & 5.542117 & 3.866150 & 1.894985 \\
\hline C & -6.187933 & -3.045456 & 1.197704 \\
\hline $\mathrm{C}$ & 1.500147 & -0.361358 & 1.087062 \\
\hline $\mathrm{N}$ & 2.410770 & -4.075216 & 1.620044 \\
\hline $\mathrm{N}$ & 6.774142 & 1.728982 & 2.329558 \\
\hline $\mathrm{N}$ & -6.976618 & -1.150677 & 2.666276 \\
\hline $\mathrm{N}$ & 3.388069 & -5.315146 & 3.148664 \\
\hline $\mathrm{N}$ & 4.799139 & 1.545152 & 1.228434 \\
\hline $\mathrm{N}$ & -5.235155 & -0.707570 & 1.402050 \\
\hline $\mathrm{N}$ & -2.393667 & -1.949939 & 0.460787 \\
\hline $\mathrm{N}$ & -0.464070 & -3.078746 & 0.450326 \\
\hline $\mathrm{C}$ & 3.354018 & -3.302064 & 2.271756 \\
\hline $\mathrm{C}$ & 6.526711 & 0.401559 & 2.066628 \\
\hline C & -6.661047 & 0.176499 & 2.901983 \\
\hline C & 3.976961 & -4.065352 & 3.236185 \\
\hline C & 5.319365 & 0.270845 & 1.386671 \\
\hline C & -5.569349 & 0.436314 & 2.10036 \\
\hline $\mathrm{C}$ & -2.219960 & -2.505989 & 1.713991 \\
\hline C & -1.023273 & -3.203769 & 1.707240 \\
\hline $\mathrm{C}$ & 2.445616 & -5.301890 & 2.160209 \\
\hline C & 5.719733 & 2.379872 & 1.815356 \\
\hline $\mathrm{C}$ & -6.105540 & -1.666206 & 1.749654 \\
\hline C & 2.197810 & -0.678897 & -0.197410 \\
\hline C & -1.315574 & -2.314419 & -0.274278 \\
\hline $\mathrm{N}$ & 2.874044 & 0.241855 & -0.925783 \\
\hline N & 2.230505 & -1.895140 & -0.794564 \\
\hline $\mathrm{N}$ & -5.022032 & -1.810263 & -1.545339 \\
\hline N & 4.504972 & 3.035438 & -1.580791 \\
\hline $\mathrm{N}$ & 1.561868 & -5.197705 & -1.223229 \\
\hline C & -1.075977 & -1.881749 & -1.684446 \\
\hline C & 3.355282 & -0.416295 & -2.040673 \\
\hline C & 2.953739 & -1.739589 & -1.962309 \\
\hline $\mathrm{C}$ & -4.788707 & -3.104887 & -1.979419 \\
\hline C & -6.352767 & -1.578937 & -1.812461 \\
\hline $\mathrm{C}$ & 5.790047 & 2.844028 & -1.910851 \\
\hline $\mathrm{C}$ & 4.052872 & 4.145311 & -2.268473 \\
\hline $\mathrm{C}$ & 2.699256 & -5.957649 & -1.372545 \\
\hline $\mathrm{C}$ & 0.515759 & -6.043841 & -1.552048 \\
\hline $\mathrm{C}$ & -5.987180 & -3.588319 & -2.493236 \\
\hline $\mathrm{N}$ & -6.965766 & -2.626177 & -2.381971 \\
\hline C & -7.051183 & -0.296693 & -1.469346 \\
\hline $\mathrm{N}$ & 6.155728 & 3.810675 & -2.803298 \\
\hline C & 6.707172 & 1.798092 & -1.381846 \\
\hline $\mathrm{C}$ & 5.077693 & 4.644909 & -3.044317 \\
\hline $\mathrm{N}$ & 2.444564 & -7.211774 & -1.771418 \\
\hline $\mathrm{C}$ & 4.077105 & -5.438917 & -1.087396 \\
\hline C & 1.073980 & -7.272235 & -1.889285 \\
\hline Zn & -3.929498 & -0.862736 & -0.220651 \\
\hline $\mathrm{Zn}$ & 3.448051 & 1.989281 & -0.132071 \\
\hline Zn & 1.388442 & -3.587898 & -0.136678 \\
\hline $\mathrm{H}$ & -2.034091 & -1.731369 & -2.218699 \\
\hline $\mathrm{H}$ & -0.482725 & -2.637941 & -2.23357 \\
\hline
\end{tabular}




\begin{tabular}{|c|c|c|c|}
\hline $\mathrm{H}$ & -0.512303 & -0.925422 & -1.723674 \\
\hline $\mathrm{H}$ & 2.182082 & 0.156161 & 1.792929 \\
\hline $\mathrm{H}$ & 1.115671 & -1.278014 & 1.568314 \\
\hline $\mathrm{H}$ & 0.634809 & 0.312003 & 0.916344 \\
\hline $\mathrm{H}$ & 7.024639 & 2.033273 & -0.342321 \\
\hline $\mathrm{H}$ & 7.607001 & 1.699989 & -2.018250 \\
\hline $\mathrm{H}$ & 6.194644 & 0.818789 & -1.330188 \\
\hline $\mathrm{H}$ & 6.521120 & 4.339616 & 2.097196 \\
\hline $\mathrm{H}$ & 4.858974 & 4.162229 & 2.721600 \\
\hline $\mathrm{H}$ & 5.123905 & 4.290746 & 0.958607 \\
\hline $\mathrm{H}$ & -7.955385 & -0.198027 & -2.098510 \\
\hline $\mathrm{H}$ & -6.403122 & 0.587763 & -1.632943 \\
\hline $\mathrm{H}$ & -7.381905 & -0.258846 & -0.407057 \\
\hline $\mathrm{H}$ & 2.116860 & -6.982156 & 0.851170 \\
\hline $\mathrm{H}$ & 0.637206 & -6.197839 & 1.431938 \\
\hline $\mathrm{H}$ & 1.587336 & -7.233892 & 2.558199 \\
\hline $\mathrm{H}$ & 4.229413 & -4.414063 & -1.483326 \\
\hline $\mathrm{H}$ & 4.818919 & -6.113641 & -1.553255 \\
\hline $\mathrm{H}$ & 4.302126 & -5.392779 & 0.001581 \\
\hline $\mathrm{H}$ & -6.703901 & -3.726783 & 1.901159 \\
\hline $\mathrm{H}$ & -5.176390 & -3.440148 & 0.989251 \\
\hline $\mathrm{H}$ & -6.732935 & -3.049584 & 0.227755 \\
\hline $\mathrm{H}$ & 7.226651 & -0.388542 & 2.372028 \\
\hline $\mathrm{H}$ & 4.818640 & -0.610272 & 0.965385 \\
\hline $\mathrm{H}$ & 3.531174 & -2.254175 & 2.008565 \\
\hline $\mathrm{H}$ & 4.763231 & -3.830811 & 3.959198 \\
\hline $\mathrm{H}$ & 5.133587 & 5.494674 & -3.730404 \\
\hline $\mathrm{H}$ & 3.025818 & 4.506898 & -2.151487 \\
\hline $\mathrm{H}$ & 3.941132 & 0.102626 & -2.807641 \\
\hline $\mathrm{H}$ & 3.116568 & -2.577480 & -2.649302 \\
\hline $\mathrm{H}$ & -0.529233 & -3.773165 & 2.502275 \\
\hline $\mathrm{H}$ & -2.958156 & -2.366755 & 2.511807 \\
\hline $\mathrm{H}$ & -3.800139 & -3.572995 & -1.891666 \\
\hline $\mathrm{H}$ & -6.188803 & -4.568506 & -2.946401 \\
\hline $\mathrm{H}$ & -5.009052 & 1.367618 & 1.972450 \\
\hline $\mathrm{H}$ & -7.223815 & 0.799380 & 3.602867 \\
\hline $\mathrm{H}$ & 7.085990 & 3.899790 & -3.213301 \\
\hline $\mathrm{H}$ & 3.624053 & -6.130183 & 3.715406 \\
\hline $\mathrm{H}$ & -7.749121 & -1.667504 & 3.087516 \\
\hline $\mathrm{Ni}$ & -1.903850 & 4.733849 & -0.155818 \\
\hline $\mathrm{C}$ & -2.193748 & 1.727228 & 1.368979 \\
\hline $\mathrm{N}$ & 1.888446 & 3.138982 & 0.336313 \\
\hline $\mathrm{N}$ & -0.118917 & 4.132086 & 0.313046 \\
\hline $\mathrm{C}$ & 1.766814 & 3.871113 & 1.500860 \\
\hline C & 0.529251 & 4.488187 & 1.484997 \\
\hline $\mathrm{C}$ & -2.737013 & 1.944409 & -0.005670 \\
\hline $\mathrm{C}$ & 0.730408 & 3.313928 & -0.356107 \\
\hline $\mathrm{N}$ & -2.656688 & 3.105930 & -0.703185 \\
\hline $\mathrm{N}$ & -3.381712 & 0.992833 & -0.729128 \\
\hline $\mathrm{C}$ & 0.422858 & 2.641084 & -1.655199 \\
\hline $\mathrm{C}$ & -3.271834 & 2.879867 & -1.922284 \\
\hline C & -3.713553 & 1.569297 & -1.939640 \\
\hline $\mathrm{H}$ & -0.182476 & 3.296535 & -2.309029 \\
\hline $\mathrm{H}$ & -0.166265 & 1.711781 & -1.501520 \\
\hline $\mathrm{H}$ & 1.352999 & 2.353841 & -2.180527 \\
\hline $\mathrm{H}$ & -1.127240 & 2.020595 & 1.426248 \\
\hline $\mathrm{H}$ & -2.281091 & 0.660014 & 1.647825 \\
\hline $\mathrm{H}$ & -2.726320 & 2.338660 & 2.128137 \\
\hline $\mathrm{H}$ & 2.568294 & 3.901851 & 2.246137 \\
\hline $\mathrm{H}$ & 0.065537 & 5.152423 & 2.222904 \\
\hline $\mathrm{H}$ & -3.345374 & 3.660681 & -2.685350 \\
\hline $\mathrm{H}$ & -4.232636 & 1.000772 & -2.719320 \\
\hline $\mathrm{H}$ & 0.562491 & -8.185673 & -2.222014 \\
\hline $\mathrm{H}$ & -0.526996 & -5.702394 & -1.526870 \\
\hline $\mathrm{C}$ & -3.469088 & 5.781114 & -0.385313 \\
\hline $\mathrm{H}$ & -3.784461 & 5.897489 & -1.438147 \\
\hline $\mathrm{H}$ & -4.294692 & 5.472796 & 0.283258 \\
\hline C & -2.696387 & 7.291459 & 1.569957 \\
\hline $\mathrm{H}$ & -1.750602 & 7.734154 & 1.949890 \\
\hline $\mathrm{H}$ & -2.935339 & 6.445270 & 2.248911 \\
\hline C & -3.814043 & 8.333934 & 1.611185 \\
\hline
\end{tabular}

$\begin{array}{lrrr}\mathrm{H} & -3.963957 & 8.724808 & 2.637302 \\ \mathrm{H} & -3.583570 & 9.197798 & 0.953408 \\ \mathrm{H} & -4.775979 & 7.902922 & 1.266334 \\ \mathrm{C} & -2.475016 & 6.735726 & 0.155216 \\ \mathrm{H} & -2.205191 & 7.542391 & -0.561260 \\ \mathrm{H} & -1.373045 & 6.219137 & 0.207520 \\ -\end{array}$

\section{0}

5-6. TS-betaH-elimi SCF Done: -4993.67092564 A.U.

\begin{tabular}{|c|c|c|c|}
\hline C & -1.968659 & 6.361363 & 1.816810 \\
\hline C & -5.384019 & -4.186985 & 1.832160 \\
\hline $\mathrm{C}$ & 6.012430 & 3.217951 & 1.149209 \\
\hline $\mathrm{C}$ & -1.570339 & 0.244911 & 1.121350 \\
\hline $\mathrm{N}$ & -2.638298 & 3.921133 & 1.679292 \\
\hline $\mathrm{N}$ & -6.720387 & -2.115902 & 2.277324 \\
\hline $\mathrm{N}$ & 6.942379 & 1.302129 & 2.503250 \\
\hline $\mathrm{N}$ & -3.657959 & 5.113799 & 3.217275 \\
\hline $\mathrm{N}$ & -4.742125 & -1.824810 & 1.205254 \\
\hline $\mathrm{N}$ & 5.173474 & 0.832389 & 1.287290 \\
\hline $\mathrm{N}$ & 2.257927 & 2.007967 & 0.448396 \\
\hline $\mathrm{N}$ & 0.278384 & 3.045682 & 0.494905 \\
\hline C & -3.553570 & 3.109904 & 2.324697 \\
\hline $\mathrm{C}$ & -6.532497 & -0.774913 & 2.034553 \\
\hline C & 6.696751 & -0.047101 & 2.691589 \\
\hline $\mathrm{C}$ & -4.202582 & 3.843370 & 3.295041 \\
\hline C & -5.324359 & -0.578523 & 1.372311 \\
\hline $\mathrm{C}$ & 5.586977 & -0.323374 & 1.920867 \\
\hline $\mathrm{C}$ & 2.078022 & 2.522741 & 1.718032 \\
\hline $\mathrm{C}$ & 0.850221 & 3.164199 & 1.746666 \\
\hline $\mathrm{C}$ & -2.715820 & 5.141531 & 2.229019 \\
\hline $\mathrm{C}$ & -5.630144 & -2.709710 & 1.769186 \\
\hline $\mathrm{C}$ & 6.013043 & 1.814814 & 1.644153 \\
\hline $\mathrm{C}$ & -2.263128 & 0.539326 & -0.170982 \\
\hline $\mathrm{C}$ & 1.153380 & 2.341267 & -0.261511 \\
\hline $\mathrm{N}$ & -2.871748 & -0.409801 & -0.922465 \\
\hline $\mathrm{N}$ & -2.361440 & 1.760101 & -0.750910 \\
\hline $\mathrm{N}$ & 4.839834 & 2.023500 & -1.616195 \\
\hline $\mathrm{N}$ & -4.355473 & -3.285161 & -1.607643 \\
\hline $\mathrm{N}$ & -1.814777 & 5.092660 & -1.156872 \\
\hline $\mathrm{C}$ & 0.913694 & 1.937093 & -1.680235 \\
\hline $\mathrm{C}$ & -3.376956 & 0.234991 & -2.034742 \\
\hline $\mathrm{C}$ & -3.057757 & 1.578820 & -1.931277 \\
\hline C & 4.555906 & 3.324830 & -1.996725 \\
\hline $\mathrm{C}$ & 6.169272 & 1.843213 & -1.925383 \\
\hline C & -5.644492 & -3.147277 & -1.949393 \\
\hline $\mathrm{C}$ & -3.855218 & -4.384258 & -2.279620 \\
\hline C & -2.973935 & 5.818046 & -1.309810 \\
\hline $\mathrm{C}$ & -0.792752 & 5.974457 & -1.467357 \\
\hline C & 5.725146 & 3.862987 & -2.523366 \\
\hline $\mathrm{N}$ & 6.735081 & 2.928237 & -2.471998 \\
\hline $\mathrm{C}$ & 6.911967 & 0.569835 & -1.649033 \\
\hline $\mathrm{N}$ & -5.964981 & -4.136412 & -2.834262 \\
\hline $\mathrm{C}$ & -6.606405 & -2.134712 & -1.435554 \\
\hline $\mathrm{C}$ & -4.853757 & -4.930995 & -3.057729 \\
\hline $\mathrm{N}$ & -2.755300 & 7.083381 & -1.694216 \\
\hline $\mathrm{C}$ & -4.337013 & 5.252669 & -1.043446 \\
\hline $\mathrm{C}$ & -1.386236 & 7.187953 & -1.798376 \\
\hline $\mathrm{Zn}$ & 3.817101 & 0.998429 & -0.293757 \\
\hline $\mathrm{Zn}$ & -3.364121 & -2.191331 & -0.152370 \\
\hline $\mathrm{Zn}$ & -1.597881 & 3.484430 & -0.075285 \\
\hline $\mathrm{H}$ & 1.870370 & 1.844465 & -2.229925 \\
\hline $\mathrm{H}$ & 0.281839 & 2.681968 & -2.201182 \\
\hline $\mathrm{H}$ & 0.391383 & 0.958646 & -1.739215 \\
\hline $\mathrm{H}$ & -2.245148 & -0.287333 & 1.823364 \\
\hline $\mathrm{H}$ & -1.213111 & 1.172726 & 1.601989 \\
\hline $\mathrm{H}$ & -0.688170 & -0.408143 & 0.959474 \\
\hline $\mathrm{H}$ & -6.932653 & -2.383157 & -0.401828 \\
\hline $\mathrm{H}$ & -7.498435 & -2.067414 & -2.086815 \\
\hline $\mathrm{H}$ & -6.129398 & -1.138197 & -1.375168 \\
\hline $\mathrm{H}$ & -6.343418 & -4.709298 & 2.006102 \\
\hline
\end{tabular}




\begin{tabular}{|c|c|c|c|}
\hline $\mathrm{H}$ & -4.705766 & -4.463285 & 2.669546 \\
\hline $\mathrm{H}$ & -4.926207 & -4.577383 & 0.899520 \\
\hline $\mathrm{H}$ & 7.810763 & 0.528403 & -2.292097 \\
\hline $\mathrm{H}$ & 6.289086 & -0.326044 & -1.846354 \\
\hline $\mathrm{H}$ & 7.255937 & 0.493935 & -0.593059 \\
\hline $\mathrm{H}$ & -2.444187 & 6.841886 & 0.933016 \\
\hline $\mathrm{H}$ & -0.939465 & 6.101983 & 1.506364 \\
\hline $\mathrm{H}$ & -1.921840 & 7.097887 & 2.641791 \\
\hline $\mathrm{H}$ & -4.457193 & 4.233123 & -1.463642 \\
\hline $\mathrm{H}$ & -5.096248 & 5.915508 & -1.498091 \\
\hline $\mathrm{H}$ & -4.565308 & 5.174937 & 0.043048 \\
\hline $\mathrm{H}$ & 6.522586 & 3.893196 & 1.862736 \\
\hline $\mathrm{H}$ & 4.976987 & 3.573014 & 0.993895 \\
\hline $\mathrm{H}$ & 6.521418 & 3.287009 & 0.162443 \\
\hline $\mathrm{H}$ & -7.272767 & -0.022708 & 2.340495 \\
\hline $\mathrm{H}$ & -4.861499 & 0.331129 & 0.968722 \\
\hline $\mathrm{H}$ & -3.692842 & 2.058557 & 2.052407 \\
\hline $\mathrm{H}$ & -4.979879 & 3.576034 & 4.016360 \\
\hline $\mathrm{H}$ & -4.871095 & -5.789838 & -3.734494 \\
\hline $\mathrm{H}$ & -2.816727 & -4.706567 & -2.150030 \\
\hline $\mathrm{H}$ & -3.918685 & -0.307010 & -2.818030 \\
\hline $\mathrm{H}$ & -3.260538 & 2.415077 & -2.609564 \\
\hline $\mathrm{H}$ & 0.343332 & 3.690190 & 2.563309 \\
\hline $\mathrm{H}$ & 2.833821 & 2.397436 & 2.501679 \\
\hline $\mathrm{H}$ & 3.556461 & 3.757985 & -1.864737 \\
\hline $\mathrm{H}$ & 5.885073 & 4.864312 & -2.945877 \\
\hline $\mathrm{H}$ & 5.065082 & -1.274001 & 1.773062 \\
\hline $\mathrm{H}$ & 7.314624 & -0.672143 & 3.342370 \\
\hline $\mathrm{H}$ & -6.887850 & -4.266289 & -3.250101 \\
\hline $\mathrm{H}$ & -3.922348 & 5.915489 & 3.790490 \\
\hline $\mathrm{H}$ & 7.706718 & 1.836199 & 2.917940 \\
\hline $\mathrm{Ni}$ & 2.066037 & -4.754040 & -0.107228 \\
\hline $\mathrm{C}$ & 2.251485 & -1.692056 & 1.306706 \\
\hline $\mathrm{N}$ & -1.752907 & -3.268649 & 0.331032 \\
\hline $\mathrm{N}$ & 0.269520 & -4.222577 & 0.308078 \\
\hline $\mathrm{C}$ & -1.621344 & -4.008343 & 1.491121 \\
\hline $\mathrm{C}$ & -0.377994 & -4.607648 & 1.472319 \\
\hline $\mathrm{C}$ & 2.748882 & -1.856795 & -0.094541 \\
\hline $\mathrm{C}$ & -0.592894 & -3.410447 & -0.360181 \\
\hline $\mathrm{N}$ & 2.672148 & -3.007800 & -0.805991 \\
\hline $\mathrm{N}$ & 3.307639 & -0.859711 & -0.829252 \\
\hline $\mathrm{C}$ & -0.321845 & -2.729453 & -1.663254 \\
\hline $\mathrm{C}$ & 3.194768 & -2.725063 & -2.054348 \\
\hline $\mathrm{C}$ & 3.584597 & -1.396511 & -2.071181 \\
\hline $\mathrm{H}$ & 0.290078 & -3.362346 & -2.331661 \\
\hline $\mathrm{H}$ & 0.236915 & -1.780565 & -1.520330 \\
\hline $\mathrm{H}$ & -1.271097 & -2.475010 & -2.170990 \\
\hline $\mathrm{H}$ & 1.152946 & -1.835245 & 1.360950 \\
\hline $\mathrm{H}$ & 2.482419 & -0.678863 & 1.685427 \\
\hline $\mathrm{H}$ & 2.694491 & -2.442809 & 1.993513 \\
\hline $\mathrm{H}$ & -2.424658 & -4.059549 & 2.233103 \\
\hline $\mathrm{H}$ & 0.093613 & -5.281969 & 2.192949 \\
\hline $\mathrm{H}$ & 3.240978 & -3.477659 & -2.849399 \\
\hline $\mathrm{H}$ & 4.034826 & -0.792152 & -2.866803 \\
\hline $\mathrm{H}$ & -0.900680 & 8.120222 & -2.117418 \\
\hline $\mathrm{H}$ & 0.259942 & 5.665722 & -1.434145 \\
\hline $\mathrm{C}$ & 3.798515 & -5.364583 & 0.642049 \\
\hline $\mathrm{H}$ & 4.308928 & -4.403690 & 0.856131 \\
\hline $\mathrm{C}$ & 3.713120 & -5.735462 & -0.712064 \\
\hline $\mathrm{H}$ & 3.494240 & -6.781277 & -0.985748 \\
\hline $\mathrm{H}$ & 4.180330 & -5.111126 & -1.488980 \\
\hline $\mathrm{H}$ & 1.714166 & -6.036115 & 0.431008 \\
\hline $\mathrm{C}$ & 3.772527 & -6.316143 & 1.815486 \\
\hline $\mathrm{H}$ & 3.254163 & -7.253834 & 1.525178 \\
\hline $\mathrm{H}$ & 3.175900 & -5.872382 & 2.641756 \\
\hline $\mathrm{C}$ & 5.191491 & -6.621902 & 2.317148 \\
\hline $\mathrm{H}$ & 5.167909 & -7.306365 & 3.188743 \\
\hline $\mathrm{H}$ & 5.801477 & -7.098516 & 1.523073 \\
\hline $\mathrm{H}$ & 5.718555 & -5.696624 & 2.630248 \\
\hline
\end{tabular}

130
6. Ni-H-Bu SCF Done: -4993.67402666 A.U.

\begin{tabular}{|c|c|c|c|}
\hline & & & \\
\hline C & -2.105999 & 6.341381 & 1.742518 \\
\hline C & -5.283786 & -4.245476 & 1.919631 \\
\hline C & 5.941928 & 3.297694 & 1.165450 \\
\hline C & -1.584314 & 0.230541 & 1.120053 \\
\hline $\mathrm{N}$ & -2.731466 & 3.888771 & 1.624895 \\
\hline $\mathrm{N}$ & -6.657845 & -2.191889 & 2.329990 \\
\hline $\mathrm{N}$ & 6.884018 & 1.404339 & 2.542440 \\
\hline $\mathrm{N}$ & -3.771638 & 5.074545 & 3.154404 \\
\hline $\mathrm{N}$ & -4.693934 & -1.885684 & 1.235774 \\
\hline $\mathrm{N}$ & 5.122275 & 0.906834 & 1.326975 \\
\hline $\mathrm{N}$ & 2.198550 & 2.048185 & 0.452790 \\
\hline $\mathrm{N}$ & 0.206101 & 3.061783 & 0.467244 \\
\hline C & -3.629905 & 3.065483 & 2.278583 \\
\hline C & -6.498490 & -0.853150 & 2.056230 \\
\hline C & 6.649244 & 0.055173 & 2.744475 \\
\hline C & -4.291577 & 3.794533 & 3.243680 \\
\hline C & -5.299619 & -0.647766 & 1.379995 \\
\hline C & 5.543857 & -0.238628 & 1.973917 \\
\hline C & 1.999930 & 2.576158 & 1.714190 \\
\hline C & 0.764167 & 3.202770 & 1.722950 \\
\hline C & -2.831409 & 5.111953 & 2.164669 \\
\hline C & -5.559950 & -2.775216 & 1.826148 \\
\hline $\mathrm{C}$ & 5.952662 & 1.899991 & 1.675529 \\
\hline C & -2.273706 & 0.493016 & -0.180916 \\
\hline $\mathrm{C}$ & 1.097083 & 2.359393 & -0.271968 \\
\hline $\mathrm{N}$ & -2.857305 & -0.479260 & -0.922764 \\
\hline $\mathrm{N}$ & -2.398348 & 1.704116 & -0.776060 \\
\hline $\mathrm{N}$ & 4.797708 & 2.064484 & -1.590799 \\
\hline $\mathrm{N}$ & -4.303902 & -3.401039 & -1.542673 \\
\hline $\mathrm{N}$ & -1.910498 & 5.047793 & -1.220637 \\
\hline $\mathrm{C}$ & 0.876151 & 1.935757 & -1.688076 \\
\hline C & -3.373603 & 0.139976 & -2.044479 \\
\hline $\mathrm{C}$ & -3.085955 & 1.492000 & -1.956565 \\
\hline C & 4.504369 & 3.357950 & -1.990447 \\
\hline C & 6.130281 & 1.891816 & -1.890632 \\
\hline $\mathrm{C}$ & -5.597792 & -3.288107 & -1.875102 \\
\hline C & -3.801142 & -4.521841 & -2.176123 \\
\hline $\mathrm{C}$ & -3.078531 & 5.754878 & -1.390627 \\
\hline $\mathrm{C}$ & -0.898432 & 5.942283 & -1.527773 \\
\hline $\mathrm{C}$ & 5.671698 & 3.899390 & -2.518010 \\
\hline $\mathrm{N}$ & 6.689462 & 2.974373 & -2.448852 \\
\hline $\mathrm{C}$ & 6.882885 & 0.628871 & -1.593683 \\
\hline $\mathrm{N}$ & -5.918932 & -4.314010 & -2.716655 \\
\hline C & -6.563743 & -2.265612 & -1.389402 \\
\hline C & -4.803149 & -5.107402 & -2.920792 \\
\hline $\mathrm{N}$ & -2.874628 & 7.020339 & -1.782540 \\
\hline C & -4.436007 & 5.171245 & -1.135690 \\
\hline $\mathrm{C}$ & -1.506283 & 7.144359 & -1.873914 \\
\hline $\mathrm{Zn}$ & 3.773538 & 1.046338 & -0.263508 \\
\hline $\mathrm{Zn}$ & -3.317646 & -2.256427 & -0.123528 \\
\hline $\mathrm{Zn}$ & -1.676123 & 3.454618 & -0.120932 \\
\hline $\mathrm{H}$ & 1.839715 & 1.841219 & -2.225213 \\
\hline $\mathrm{H}$ & 0.246860 & 2.670971 & -2.225661 \\
\hline $\mathrm{H}$ & 0.358980 & 0.954267 & -1.740639 \\
\hline $\mathrm{H}$ & -2.268124 & -0.263071 & 1.841661 \\
\hline $\mathrm{H}$ & -1.207036 & 1.167334 & 1.566564 \\
\hline $\mathrm{H}$ & -0.717595 & -0.447028 & 0.978700 \\
\hline $\mathrm{H}$ & -6.886268 & -2.485279 & -0.348010 \\
\hline $\mathrm{H}$ & -7.457804 & -2.222411 & -2.040004 \\
\hline $\mathrm{H}$ & -6.091437 & -1.265577 & -1.360592 \\
\hline $\mathrm{H}$ & -6.231079 & -4.782778 & 2.113132 \\
\hline $\mathrm{H}$ & -4.593249 & -4.489706 & 2.756933 \\
\hline $\mathrm{H}$ & -4.825704 & -4.647138 & 0.991953 \\
\hline $\mathrm{H}$ & 7.783273 & 0.585256 & -2.234402 \\
\hline $\mathrm{H}$ & 6.267778 & -0.274935 & -1.778800 \\
\hline $\mathrm{H}$ & 7.225744 & 0.571631 & -0.536135 \\
\hline $\mathrm{H}$ & -2.591131 & 6.808482 & 0.856834 \\
\hline $\mathrm{H}$ & -1.073595 & 6.096645 & 1.430798 \\
\hline $\mathrm{H}$ & -2.069085 & 7.083980 & 2.562549 \\
\hline $\mathrm{H}$ & -4.544149 & 4.155954 & -1.569457 \\
\hline
\end{tabular}




\begin{tabular}{|c|c|c|}
\hline-5.200371 & 5.831546 & -1.585321 \\
\hline-4.666909 & 5.077281 & -0.051139 \\
\hline 6.437673 & 3.986174 & 1.876501 \\
\hline 4.904319 & 3.639563 & 0.995997 \\
\hline 6.459718 & 3.361608 & 0.182909 \\
\hline-7.251313 & -0.109069 & 2.351244 \\
\hline-4.859411 & 0.261364 & 0.950836 \\
\hline-3.748916 & 2.009213 & 2.016061 \\
\hline-5.062474 & 3.518227 & 3.968479 \\
\hline-4.820055 & -5.992602 & -3.562718 \\
\hline-2.758831 & -4.831051 & -2.045166 \\
\hline-3.898728 & -0.424111 & -2.823503 \\
\hline-3.304746 & 2.314232 & -2.646870 \\
\hline 0.242892 & 3.732799 & 2.527854 \\
\hline 2.749568 & 2.469910 & 2.506538 \\
\hline 3.500300 & 3.783773 & -1.870127 \\
\hline 5.825079 & 4.896302 & -2.953197 \\
\hline 5.029880 & -1.195029 & 1.836157 \\
\hline 7.270271 & -0.557617 & 3.403866 \\
\hline-6.845138 & -4.468272 & -3.116427 \\
\hline-4.050455 & 5.875747 & 3.721423 \\
\hline 7.642632 & 1.949235 & 2.953566 \\
\hline 2.133883 & -4.748934 & -0.088431 \\
\hline 2.240858 & -1.667442 & 1.342980 \\
\hline-1.686901 & -3.298638 & 0.369550 \\
\hline 0.339079 & -4.241518 & 0.334421 \\
\hline-1.527660 & -4.002504 & 1.548282 \\
\hline-0.281641 & -4.596208 & 1.522486 \\
\hline 2.740983 & -1.824233 & -0.057874 \\
\hline-0.540403 & -3.454890 & -0.340826 \\
\hline 2.684778 & -2.977092 & -0.767405 \\
\hline 3.289908 & -0.821043 & -0.791722 \\
\hline-0.298910 & -2.812943 & -1.668787 \\
\hline 3.213799 & -2.691643 & -2.011902 \\
\hline 3.584415 & -1.357495 & -2.029749 \\
\hline 0.321783 & -3.455524 & -2.319546 \\
\hline 0.237467 & -1.846431 & -1.563892 \\
\hline-1.258770 & -2.599433 & -2.175781 \\
\hline 1.144760 & -1.827276 & 1.397870 \\
\hline 2.456482 & -0.651059 & 1.722195 \\
\hline 2.696722 & -2.412392 & 2.027990 \\
\hline-2.315967 & -4.036895 & 2.307193 \\
\hline 0.207277 & -5.249196 & 2.251070 \\
\hline 3.275132 & -3.444030 & -2.805998 \\
\hline 4.029262 & -0.748172 & -2.824627 \\
\hline-1.031296 & 8.081328 & -2.195084 \\
\hline 0.158243 & 5.649341 & -1.481089 \\
\hline 4.073575 & -5.159486 & 0.372705 \\
\hline 4.589982 & -4.187695 & 0.270133 \\
\hline 3.686256 & -5.816558 & -0.803738 \\
\hline 3.476933 & -6.897944 & -0.798541 \\
\hline 3.921549 & -5.373288 & -1.785207 \\
\hline 1.714544 & -6.057230 & 0.396702 \\
\hline 4.222964 & -5.821608 & 1.719207 \\
\hline 3.678484 & -6.788331 & 1.722922 \\
\hline 3.738712 & -5.189184 & 2.496375 \\
\hline 5.700295 & -6.031777 & 2.087132 \\
\hline 5.800354 & -6.496826 & 3.088354 \\
\hline 6.204642 & -6.690423 & 1.351274 \\
\hline 6.253133 & -5.069567 & 2.104547 \\
\hline
\end{tabular}

